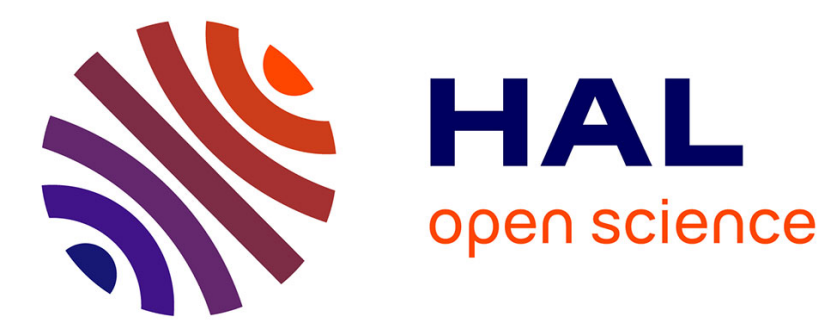

\title{
Pressure drops, heat transfer coefficient, costs and power block design for direct storage parabolic trough power plants running molten salts
}

\author{
Telma Lopes, Thomas Fasquelle 3+, Hugo G Silva
}

\section{- To cite this version:}

Telma Lopes, Thomas Fasquelle 3+, Hugo G Silva. Pressure drops, heat transfer coefficient, costs and power block design for direct storage parabolic trough power plants running molten salts. Renewable Energy, 2021, 163, pp.530-543. hal-03094733

\section{HAL Id: hal-03094733 \\ https://hal.science/hal-03094733}

Submitted on 4 Jan 2021

HAL is a multi-disciplinary open access archive for the deposit and dissemination of scientific research documents, whether they are published or not. The documents may come from teaching and research institutions in France or abroad, or from public or private research centers.
L'archive ouverte pluridisciplinaire $\mathbf{H A L}$, est destinée au dépôt et à la diffusion de documents scientifiques de niveau recherche, publiés ou non, émanant des établissements d'enseignement et de recherche français ou étrangers, des laboratoires publics ou privés. 


\section{Pressure drops, heat transfer coefficient, costs and power block design for}

2 direct storage parabolic trough power plants running molten salts

3 Telma Lopes ${ }^{1,2}$, Thomas Fasquelle ${ }^{3+}$, Hugo G. Silva ${ }^{4}$,

4 telma.lopes@emiatomo.eu,thomas.fasquelle@univ-amu.fr,hgsilva@uevora.pt

5 IEMIÁTOMO-Projetos e Manutenção Industrial,Lda, Edifício Zils, Monte Feio, Escritório 515,

6 7520-064 Sines, Portugal

$7 \quad{ }^{2}$ Renewable Energy Chair, University of Évora, Portugal

$8{ }^{3}$ Aix Marseille Univ, CNRS, IUSTI, Marseille, France

$9{ }^{4}$ Department of Physics and Earth Sciences Institute, School of Sciences and Technology,

10 University of Évora, Rua Romão Ramalho, 59, 7000-671, Évora, Portugal.

$11 \quad{ }^{+}$Corresponding author: thomas.fasquelle@univ-amu.fr

12

13 Highlights

14 - Molten salts versus thermal oils as heat transfer fluids;

15 - Molten salts show lower pumping electric consumption;

16 - A minimum LCOE reduction of $>6 \%$ is expected with HitecXL;

17 - Simpler power block for molten salt technology can be achieved. 
19 Direct circulation of molten salts in the solar field of parabolic trough solar power plants may be

20 a possible breakthrough to decrease their levelized cost of electricity. While prototypes are being

21 erected around the world, this study addresses the main concerns and changes that are related to

22 the replacement of thermal oils by molten salts, i.e. pressure drops, heat transfer coefficient, anti-

23 freezing solutions, cost and power block design. It combines: 1) an analytical comparison of both

24 technologies with respect to pressure drops and heat transfers; 2) simulations of a

$2550 \mathrm{MW}_{\mathrm{e}} / 7.5$ hours-of-storage power plant, using NREL's SAM software, providing details on

26 the dynamics of the outputs and parasitics. It has been observed the following: 1) pressure drops

27 in the solar field are smaller running molten salts instead of thermal oil, thanks to higher

28 operating temperature ranges; 2) HitecXL molten salt leads to lower electricity consumption than

29 Therminol VP-1 oil and Solar Salt (parasitics); 3) a $6.3 \%$ reduction of the levelized cost of

30 electricity when running HitecXL, $14.80 \mathrm{c} € / \mathrm{kWh}$, instead of Therminol VP-1, $15.80 \mathrm{c} € / \mathrm{kWh}$;

31 4) simpler power block designs can be considered for the higher operating temperatures of

32 molten salts, resulting in higher efficiencies and/or cheaper power blocks. 


\begin{tabular}{|c|c|c|c|}
\hline \multicolumn{2}{|r|}{ Acronyms } & \multicolumn{2}{|r|}{ Variables } \\
\hline ASE & Archimede Solar Energy & beam & Normal direct solar irradiance \\
\hline$C A P E X$ & CAPital EXpenditures & C & Specific heat $\left[\mathrm{J}^{\mathrm{kg}} \mathrm{kg}^{-1} \cdot \mathrm{K}^{-1}\right]$ \\
\hline $\begin{array}{c}\mathrm{CF} \\
\mathrm{CSP}\end{array}$ & $\begin{array}{l}\text { Capacity Factor } \\
\text { Concentrated Solar Power }\end{array}$ & $C_{n_{y}}$ & Total cost for year $n_{y}[€$ or $\$]$ \\
\hline DLR & German Aerospace Centre & $D_{r t}$ & Pipe diameter $[\mathrm{m}]$ \\
\hline HTF & Heat Transfer Fluid & $E_{n_{y}}$ & $\begin{array}{l}\text { annual electricity production for } \\
\text { year } n_{y}[\mathrm{kWh}]\end{array}$ \\
\hline LCOE & Levelized Cost of Electricity & $F_{X}$ & $\begin{array}{l}\text { Variable to nullify for friction } \\
\text { factor calculation }\end{array}$ \\
\hline MATS & $\begin{array}{l}\text { Multipurpose Applications by } \\
\text { Thermodynamic Solar }\end{array}$ & $h$ & Convection coefficient $\left[\mathrm{W} \cdot \mathrm{m}^{-2} \cdot \mathrm{K}^{-1}\right]$ \\
\hline$M S$ & Molten Salt & $h_{x}$ & Specific enthalpy at point $\mathrm{x}\left[\mathrm{J} \cdot \mathrm{kg}^{-1}\right]$ \\
\hline MSPT & Molten Salt Parabolic Trough & $k$ & Thermal conductivity $\left[\mathrm{W} \cdot \mathrm{m}^{-1} \cdot \mathrm{K}^{-1}\right]$ \\
\hline NREL & $\begin{array}{l}\text { National Renewable Energy } \\
\text { Laboratory }\end{array}$ & $\dot{m}$ & Mass flow $\left[\mathrm{kg} \cdot \mathrm{s}^{-1}\right]$ \\
\hline$O P E X$ & OPerational EXpenditures & $n$ & Factor for Dittus-Boelter equation \\
\hline$T M Y$ & Typical Meteorological Year & $n_{y}$ & Year number \\
\hline TO & Thermal Oil & $N$ & Lifespan of a project [year] \\
\hline$P T$ & Parabolic Trough & $N u$ & Nusselt number \\
\hline SAM & System Advisor Model & $\operatorname{Pr}$ & Prandtl number \\
\hline TES & Thermal Energy Storage & Pres & Atmospheric pressure $[\mathrm{Pa}]$ \\
\hline$T-S$ & Temperature-Entropy & $r$ & Discount rate \\
\hline$V H C$ & Volumetric Heat Capacity & $R e$ & Reynolds number \\
\hline & & $R H$ & Relative Humidity \\
\hline & & Rough & Relative roughness \\
\hline & Greek & $T$ & Temperature $\left[\mathrm{K}\right.$ or $\left.{ }^{\circ} \mathrm{C}\right]$ \\
\hline$\Delta$ & Finite difference & $T_{C S}$ & Cold Source temperature [K] \\
\hline$\varepsilon$ & Roughness [m] & $T_{d r y}$ & Ambient dry temperature $\left[{ }^{\circ} \mathrm{C}\right]$ \\
\hline$\rho$ & Density $\left[\mathrm{kg} \cdot \mathrm{m}^{-3}\right]$ & $T_{H S}$ & Hot Source temperature $[\mathrm{K}]$ \\
\hline$\mu$ & Dynamic Viscosity [Pa.s] & $V P 1$ & Therminol VP-1 \\
\hline & & $\bar{v}$ & Mean velocity $\left[\mathrm{m} \cdot \mathrm{s}^{-1}\right]$ \\
\hline & & $w_{s p d}$ & Wind speed $\left[\mathrm{m} . \mathrm{s}^{-1}\right]$ \\
\hline & & $\dot{W}$ & Electrical work [W] \\
\hline & & $X$ & $\begin{array}{l}\text { Variable used to calculate friction } \\
\text { factor }\end{array}$ \\
\hline
\end{tabular}




\section{Introduction}

40 Due to the population increase and the industrial development that the world has undergone over

41 the last decades, energy consumption has increased exponentially, leading to a rarefaction of the

42 resources and an accelerating global warming. With these changes, it becomes increasingly

43 important to look for other solutions that enable energy sustainability, such as renewable

44 energies. Wind energy and solar photovoltaics currently lead the market with a $284 \mathrm{GW}$ increase

45 of installed wind power capacity and a $256 \mathrm{GW}$ increase of installed solar power worldwide

46 between 2010 and 2016 [1].

47 Concentrated Solar Power (CSP) is still an expensive technology and it remains at a relatively

48 early stage, with most of the running power plants located in Spain and the United States [2]. It

49 presents the possibility of storing thermal energy cheaply and efficiently, allowing the

50 production of energy not only during the period of solar irradiation, but also during times of

51 greater demand. Moreover, Thermal Energy Storage (TES) has the capability to solve the solar

52 intermittency problem (cloud passage, for example) responsible for possible disturbances in the

53 electrical grid.

54 Most of the commercial CSP systems installed around the world use parabolic trough (PT)

55 collectors as concentration elements and thermal oils (TO) as heat transfer fluid (HTF) [3] and

56 those having TES, use molten salts (MS) as energy storage fluid, yet many do not [4]. The reason

57 why MS are used as heat storage fluid stems from their high thermal capacity, their lower cost

58 and their thermal stability (no risks of ignition).

59 The possibility of using MS also as HTF has been the subject of various investigations $[5,6,7]$,

60 since these have several advantages in relation to TO, such as the possibility of increasing the

61 output temperature of the solar field to $450-565{ }^{\circ} \mathrm{C}$ (compared to $\sim 393{ }^{\circ} \mathrm{C}$ with TO). Thus, the 
62 Rankine cycle's efficiency is expected to be increased from $~ 37.6 \%$ to slightly more than $40 \%$

63 [6]. Moreover, MS have low vapor pressure at high temperatures, high boiling temperature and

64 relatively high thermal conductivity. Their use as HTF may allow a reduction of the capital

65 expenditures (CAPEX) of the plant, by reducing the physical size of the storage system and by

66 removing the need for a heat exchanger between the HTF and the storage medium. On the other

67 hand, their use would require a careful evaluation of certain aspects such as melting point

68 (freezing issues) as well as corrosiveness and installation cost. Presently, various solar tower

69 power plants already use MS as $\operatorname{HTF}[8,9]$ because of the reduced length of piping when

70 compared to linear focusing systems. However, there is some investigation about the possibility

71 to use MS in PT power plants as well:

72 - In 2002, D. Kearney et at [5] began to investigate the feasibility of utilizing MS as both

73 HTF and TES fluid in a PT solar field to improve system performance and to reduce the

74 levelized cost of electricity (LCOE) of the plant ( $17 \%)$.

75 - Since July 2013, the first stand-alone Molten Salt Parabolic Trough (MSPT) demo plant,

76 located close to the Archimede Solar Energy (ASE) manufacturing plant in Massa

77 Martana (Perugia, Italy), is in operation. The ASE MSPT demo plant is composed of a

78 single loop with a collecting surface of $\sim 3,600 \mathrm{~m}^{2}$, equipped with high temperature solar

79 receivers and connected to a molten salt storage system constituted of two $25 \mathrm{~m}^{3}$ tanks

$80 \quad[7]$.

81 - More recently (2018), the MATS (Multipurpose Applications by Thermodynamic Solar)

82 power plant was inaugurated in Egypt [10]. It has an electrical power of $1 \mathrm{MW}$ and is

83 based on PT collectors with an area of $10,000 \mathrm{~m}^{2}$. The system uses a mixture of sodium 
nitrate and potassium nitrate as $\mathrm{HTF}$, heated from $\sim 290{ }^{\circ} \mathrm{C}$ to $\sim 550{ }^{\circ} \mathrm{C}$. The power plant also includes a heat storage system with an embedded steam generator.

86 To tackle the freezing and corrosion problems, as well as achieving higher operating

87 temperatures, a quite important range of different MS was developed within the past few years

88 [11]. Yet, to prove the feasibility of using MS as HTF, an extensive study and a test of various

89 technologies with different MS are still necessary. For instance, Boukelia et al. [12] compared

90 the use of MS (Solar Salt) and TO as HTF in PT plants. Using the System Advisor Model (SAM)

91 and the EBSILON model, they developed an artificial neural network optimizing both MS and

92 TO configurations, and found a $13 \%$ LCOE reduction with MS. However, the study does not

93 give any details about pumping consumption, strategies against freezing and does not assess the

94 performance of other MS, such as HitecXL.

95 Hence, there is still a lack of answers regarding both MS pressure drops and freezing problems,

96 along with their impact on the overall costs of the plant. Pending the completion of experimental

97 power plants and the operational data they will generate, the present study provides reliable

98 indicators to those answers (Section 2 and Section 3), as well as the implied modifications in the

99 power block designs (Section 4).

100 This work is part of the High Performance Solar 2 (HPS2) project, which is led by the University

101 of Évora and the German Aerospace Centre (DLR) and integrates a consortium of companies and

102 laboratories. Its final objective is the construction of an experimental $3.6 \mathrm{MW}_{\text {th }}$ solar plant at the

103 Évora Molten Salt Platform (EMSP) with PT solar concentrators and with MS as heat transfer

104 and storage fluid. HTF will be YaraMost MS that consists of a ternary mixture based on

105 potassium nitrate $\left(\mathrm{KNO}_{3}\right)$, sodium nitrate $\left(\mathrm{NaNO}_{3}\right)$ and as source of calcium nitrate, Yara

106 NitCal-K. 


\section{2. Analytical comparison between thermal oils and molten salts as 108 HTF}

\section{2.1. Fluid properties}

110 Relevant properties for an analytical comparison between TO and MS are presented in Table 1.

111 Thermal properties of Therminol VP-1, i.e. biphenyl and diphenyl oxide, also commercialized

112 under the name Dowtherm A; Solar Salt, $60 \% \mathrm{NaNO}_{3} / 40 \% \mathrm{KNO}_{3}$; HitecXL, $\mathrm{Ca}\left(\mathrm{NO}_{3}\right)_{2}-\mathrm{KNO}_{3^{-}}$

$113 \mathrm{NaNO}_{3}$; were estimated from correlations provided by D. Kearney et al. [5],

114 K. Vignarooban et al. [8] and A. Bonk et al. [13].

Table 1: Values of thermal properties at $350{ }^{\circ} \mathrm{C}$ for thermal oil and $400{ }^{\circ} \mathrm{C}$ for molten salts.

\begin{tabular}{|c|c|c|c|}
\hline & $\begin{array}{c}\text { Therminol VP-1 } \\
\left(* \text { at } 350^{\circ} \mathrm{C}\right)\end{array}$ & $\begin{array}{c}\text { Solar Salt } \\
\left(* \text { at } 400^{\circ} \mathrm{C}\right)\end{array}$ & $\begin{array}{c}\text { HitecXL } \\
\left(* \text { at } 400^{\circ} \mathrm{C}\right)\end{array}$ \\
\hline Melting point $\left[{ }^{\circ} \mathrm{C}\right]$ & 13 & 220 & 120 \\
\hline $\mathrm{T}_{\max }\left[{ }^{\circ} \mathrm{C}\right]$ & 400 & 600 & 500 \\
\hline Density*, $\rho\left[\mathrm{kg} \cdot \mathrm{m}^{-3}\right]$ & 761 & 1839 & 1913 \\
\hline Dynamic viscosity*, $\mu[\mathrm{Pa} . \mathrm{s}]$ & 0.000177 & 0.00182 & 0.00253 \\
\hline Specific heat*, C $\left[\mathrm{J} \cdot \mathrm{kg}^{-1} \cdot \mathrm{K}^{-1}\right]$ & 2454 & 1511 & 1400 \\
\hline Thermal conductivity*, $\mathrm{k}\left[\mathrm{W} \cdot \mathrm{m}^{-1} \cdot \mathrm{K}^{-1}\right]$ & 0.086 & 0.52 & 0.52 \\
\hline VHC* $\left[\mathrm{MJ} \cdot \mathrm{m}^{-3} \cdot \mathrm{K}^{-1}\right]$ & 1.87 & 2.78 & 2.68 \\
\hline Vapor pressure [bar] & 7 & - & - \\
\hline
\end{tabular}

116 As illustrated in Table 1, the main advantages associated with the use of MS as HTF instead of

117 TO are their higher operating temperatures, their higher Volumetric Heat Capacity $\left(\mathrm{VHC}=\rho . \mathrm{C}_{\mathrm{p}}\right)$

118 and their very low vapor pressure, inducing no risk of vaporization and therefore no need for

119 fluid pressurization. Higher energy density along with lower cost is a significant advantage when

120 considering the high volumes of materials that are needed for TES (27,000 tons of MS in an 
121 Andasol-like power plant, i.e. $50 \mathrm{MW}_{\mathrm{e}}$ and 7.5 hours of TES). On the other hand, MS have less

122 favorable properties such as a higher viscosity and a higher melting point. TO are more

123 interesting as HTF mainly because they do not present risk of freezing at ambient temperature in

124 the very long piping systems ( $\sim 90 \mathrm{~km}$ of receivers and $\sim 1.5 \mathrm{~km}$ of interconnecting piping in an

125 Andasol-like power plant), neither they pose any significant corrosion risks.

\section{$126 \quad$ 2.2. Heat transfer coefficient}

127 The heat transfer coefficient drives the thermal efficiency of the receiver tubes. Furthermore, as

128 receiver tubes collect more solar irradiation from the collector facing side, the latter tends to

129 reach higher temperatures. Thus, a low heat transfer coefficient results in a non-uniform thermal

130 expansion of the receiver tubes, leading to an undesirable bending and possibly even breaking

131 the protective glass cover $[14,15]$.

132 Here, heat transfer coefficient between fluid and pipe are estimated with the Dittus-Boelter

133 equation (1), which is valid for most fluids $(0.7<\operatorname{Pr}<160)$ in a fully turbulent regime

$134(\operatorname{Re}>10,000)$ inside a tube [16],

$$
N u=0.023 \cdot \operatorname{Re}^{0.8} \cdot \operatorname{Pr}^{n}
$$

135 with $n=0.4$ (heated fluid). Since the Nusselt number, $N u$, involves both the Prandtl number, $P r$,

136 and the Reynolds number, $R e$, all thermal properties have an impact on the heat transfer rate.

137 Hence, a comparison between the different fluids can be performed by developing this

138 expression, resulting in Equation (2), assuming identical absorbed power and the mass flow

139 depending on the fluid's specific heat:

$$
\frac{h_{M S}}{h_{T O}}=\left(\frac{C_{T O}}{C_{M S}}\right)^{0.4} \cdot\left(\frac{\mu_{T O}}{\mu_{M S}}\right)^{0.4} \cdot\left(\frac{\Delta T_{T O}}{\Delta T_{M S}}\right)^{0.8} \cdot\left(\frac{k_{M S}}{k_{T O}}\right)^{0.6}
$$


140 here, $h_{M S}$ and $h_{T O}$ are convection heat transfer coefficients, $C_{M S}$ and $C_{T O}$ are specific heats, $\mu_{M S}$

141 and $\mu_{T O}$ are viscosities, $k_{M S}$ and $k_{T O}$ are thermal conductivities, and $\Delta T_{M S}$ and $\Delta T_{T O}$ are

142 temperature differences, respectively for MS and TO. Equation (2) shows that the temperature

143 differences that are experienced by the HTF and their conductivities have larger impacts than

144 their dynamic viscosities or their specific heats. Density does not impact the convection heat

145 transfer for a given power.

146 The comparison between HitecXL and Therminol VP-1, considering a low temperature of $147290{ }^{\circ} \mathrm{C}$ for both fluids and different high temperatures $\left(\sim 390^{\circ} \mathrm{C}\right.$ for the $\mathrm{TO}, \sim 500{ }^{\circ} \mathrm{C}$ for 148 HitecXL), gives a convection coefficient 30\% lower for MS than TO:

$$
\frac{h_{\text {HitecXL }}}{h_{V P-1}}=\left(\frac{2454}{1400}\right)^{0.4} \cdot\left(\frac{0.000177}{0.00253}\right)^{0.4} \cdot\left(\frac{100}{210}\right)^{0.8} \cdot\left(\frac{0.52}{0.086}\right)^{0.6}=0.70
$$

149 To better assess those differences, details of the calculation were given for the case of a $600 \mathrm{~m}$ 150 receiver line, such as those found in conventional power plants like Andasol (Table 2). A useful 151 thermal power of $\sim 2.5 \mathrm{MW}_{\text {th }}$ was estimated for those calculations.

Table 2: Heat transfer coefficient (h) of the HTF and respective intermediate calculations.

\begin{tabular}{c|ccc} 
& Therminol VP-1 & Solar Salt & HitecXL \\
\hline$\Delta T[\mathrm{~K}]$ & 100 & 275 & 210 \\
$\dot{m}\left[\mathrm{~kg} \cdot \mathrm{s}^{-1}\right]$ & 10.2 & 6.0 & 8.5 \\
$\bar{v}\left[\mathrm{~m} \cdot \mathrm{s}^{-1}\right]$ & 3.9 & 0.96 & 1.30 \\
$\operatorname{Re}$ & $1,110,346$ & 63,773 & 64,839 \\
$P r$ & 5.1 & 5.3 & 6.8 \\
$N u$ & 3016 & 312 & 350 \\
\hline$h\left[\mathrm{~W} \cdot \mathrm{m}^{-2} \cdot \mathrm{K}^{-1}\right]$ & 3930 & 2462 & 2760 \\
\hline
\end{tabular}

153 In Table 2 the symbol $\dot{m}$ stands for fluid mass flow and $\bar{v}$ for the mean fluid velocity. For the 154 same output powers, mass flows with MS are lower than with TO, $68.5 \mathrm{~kg} . \mathrm{s}^{-1}$ vs. $10.2 \mathrm{~kg} . \mathrm{s}^{-1}$, 
155 respectively, their lower specific heat being compensated by higher operating $\Delta T$. In addition, 156 higher density of MS results in lower velocities, $0.961 .3 \mathrm{~m} . \mathrm{s}^{-1}$ vs. $3.9 \mathrm{~m} . \mathrm{s}^{-1}$, respectively, i.e.,

157 lower Reynolds number and therefore lower Nusselt numbers (Prandtl numbers being similar).

158 Nevertheless, the six-times higher thermal conductivity of the MS enables compensating those

159 smaller values, resulting in lower, but relatively close heat transfer coefficient when compared to

160 Therminol VP-1, 2462-2760 W. $\mathrm{m}^{2} . \mathrm{K}^{1}$ vs. $3930 \mathrm{~W} . \mathrm{m}^{2} . \mathrm{K}^{1}$, respectively. However, for such high

161 values of $h$, this difference should not have a significant impact on the operation of the plant.

162 Another issue would be the possible bending of the absorber tubes. Their manufacturers typically

163 claim that a $R e>20,000$ is sufficient to homogenize the temperature around them, avoiding

164 problems due to non-uniform expansion. As the obtained $R e$ values are much higher than the

165 required ones (the lowest being 63,773 for Solar Salt), the use of MS as HTF should not present

166 any risk to the receivers or the proper operation of the system.

\section{2.3. Pressure drops}

168 Since TO have lower density and viscosity than MS, they are expected to entail lower pressure

169 drops in the solar field when subjected to the same conditions. With the intention of better

170 assessing those differences, the receiver line power is set to $2.5 \mathrm{MW}_{\text {th }}$, similarly to what was

171 done for calculations of the heat transfer coefficient. Considering the velocity at which each fluid

172 circulates in the receiver tubes to achieve this power with their inlet and outlet temperatures,

173 pressure drops in the solar field are obtained with the following Equation (4):

$$
\Delta p_{\text {pipe }}=h l_{\text {pm }} \cdot \rho \cdot g \cdot L_{\text {pipe }},
$$

174 where $\rho$ represents the fluid density, $g$ the gravitational acceleration, $L_{p i p e}$ the pipe length and $175 h l_{p m}$ the head loss per meter given by Equation (5): 


$$
h l_{p m}=\frac{f r \cdot \bar{v}^{2}}{2 \cdot D_{r t} \cdot g} .
$$

176 To obtain the value of $h l_{p m}$, it is necessary to know the friction factor $f r$, the mean velocity of the

177 fluid inside the tube, $\bar{v}$, and the diameter of the receiver tube, $D_{r t}$. The friction factor is given by

178 Equation (6),

$$
f r=\frac{1}{X^{2}},
$$

179 where $X$ is obtained with Equation (7) and with $\mathrm{F}_{\mathrm{X}}=0$ :

$$
F_{X}=X+2 \cdot \log _{10}\left[\frac{\text { Rough }}{3.7}+2.51 \frac{X}{R e}\right],
$$

180 with Rough being the relative roughness of the tube $\left(\operatorname{Rough}=\varepsilon / D_{r t}\right)$ [17]. In this case, the value

181 of roughness for commercial new steel receiver tube is used, $\varepsilon=0.046 \mathrm{~mm}$, the internal diameter

182 is $D_{r t}=0.066 \mathrm{~m}$, and the Reynolds values previously calculated for the same conditions are

183 applied. Considering the different $\Delta T$ that are allowed for each fluid, $100{ }^{\circ} \mathrm{C}$ for the $\mathrm{TO}, 210{ }^{\circ} \mathrm{C}$

184 for HitecXL and $275{ }^{\circ} \mathrm{C}$ for Solar Salt, the obtained results are gathered in Table 3.

Table 3: Pressure drops values per metre [Pa.m $\left.{ }^{-1}\right]$ obtained for each HTF in their operating conditions.

\begin{tabular}{c|ccc}
\hline & Therminol VP-1 & Solar Salt & HitecXL \\
\cline { 2 - 4 }$v\left[\mathrm{~m} . \mathrm{s}^{-1}\right]$ & 3.9 & 0.96 & 1.30 \\
$X$ & 7.34 & 6.95 & 6.86 \\
$f r$ & 0.019 & 0.021 & 0.021 \\
$h[\mathrm{~m} / \mathrm{m}]$ & 0.219 & 0.015 & 0.028 \\
$\Delta p\left[\mathrm{~Pa} \cdot \mathrm{m}^{-1}\right]$ & 1636 & 264 & 520 \\
\hline
\end{tabular}

186 Contrary to what was expected, the pressure drops in the solar field are smaller when using MS 187 as HTF, 264 Pa.m ${ }^{-1}$ with Solar Salt and 520 Pa.m ${ }^{-1}$ with HitecXL, against 1636 Pa.m $^{-1}$ with TO. 188 Although TO are less dense and less viscous, MS have a larger operating $\Delta T$ which reduces the 189 flow velocity of the fluid in the receiver tube, resulting in the decrease of pressure drops. This is 190 an important result as it highlights the fact that a significant reduction in pumping electrical 
191 power consumption can be achieved by using MS rather than TO. In fact, based on the $\Delta p$

192 estimation such reductions would be around $84 \%$ when using Solar Salt and $68 \%$ when using

193 HitecXL instead of TO. These would eventually compensate the extra energy consumption for

194 MS freezing protection or even reduce the overall consumption. To validate such assumption, 195 numerical simulation results for an Andasol-like power plant are presented in the following 196 section.

\section{3. Techno economic analysis with SAM}

198 The SAM software was used to simulate the operation of a CSP power plant using different 199 fluids as HTF. SAM was developed by the National Renewable Energy Laboratory (NREL) with 200 the aim of modeling a range of renewable energies, including solar thermal PTs. SAM uses an 201 hourly performance model to estimate a power system's total annual output, as well as a cost and 202 financial model $[18,19]$. In the present analysis, SAM was used to perform an annual simulation 203 of a $50 \mathrm{MW}_{\mathrm{e}}$ power plant with 7.5 hours of TES, with local meteorological data from Évora, 204 Portugal, and inputs corresponding to the characteristics of Andasol 3 power plant [20] . A brief 205 description of the parameters used in SAM to simulate the power plant are listed in the 206 Appendix 1.

\section{3.1. Meteorological data}

208 The meteorological dataset, namely, normal direct solar irradiance-beam, ambient dry 209 temperature - $\mathrm{T}_{\mathrm{dry}}$, relative humidity $-\mathrm{RH}$, atmospheric pressure - Pres and wind speed $-\mathrm{w}_{\mathrm{spd}}$,

210 used in this work was obtained from two nearby meteorological stations in Évora, Portugal: one

211 from the Institute of Earth Sciences (38.567686N, 7.91172W) and another from Portuguese

212 Institute for the Sea and the Atmosphere (38.53654N, 7.88795W). Details on the measurement 
213 devices can be found on references [21, 22]. The meteorological data that were used are the

214 result of a compilation between years 2016, 2017 and 2018. A more accurate analysis would

215 consider typical meteorological years (TMY), instead of individual years, in order to be more

216 representative of the long period of operation, but SAM's TMY for Évora seem not to be

217 appropriate, and not enough years of data were available to calculate TMY.

\section{3.2. Annual production of energy and capacity factor}

219 In the simulation model that was used in SAM, CSP parabolic trough (physical), the annual 220 production of energy represents the amount of electricity that the plant produces during a year 221 and the value is given in $\mathrm{MW}_{\mathrm{e}} \mathrm{h}$. From this value, the capacity factor of the plant can be 222 calculated. Capacity Factor, CF, is a comparative measure of the amount of energy produced by 223 a power plant with the maximum energy that could be produced if it was operating at nominal 224 power during the same period, $c f$. Equation (8):

$$
C F=\frac{\text { Annual Energy Produced }}{\text { Maximum energy that could be produced }}
$$

225 In the present case, the nominal power of the plant is $50 \mathrm{MWe}$ and the maximum energy that 226 could be produced is calculated by multiplying the nominal power by the number of hours in a 227 year, i.e. 8760, which gives 438,000 MWeh. Through the CF it is also possible to determine how 228 many equivalent hours the plant would annually operate at nominal power, for each case (see 229 Table 4). 


\begin{tabular}{|c|c|c|c|}
\hline & Therminol VP-1 & Solar Salt & HitecXL \\
\hline Annual electricity (produced) $\left[\mathrm{MW}_{\mathrm{e}} \mathrm{h}\right]$ & 191,043 & 164,565 & 194,169 \\
\hline Capacity factor CF [\%] & 43.6 & 37.6 & 44.3 \\
\hline Number of equivalent hours at nominal power [h] & 3819 & 3294 & 3881 \\
\hline
\end{tabular}

231 Interestingly, capacity factors are very similar when comparing the results of the simulation for

232 Therminol VP-1 and HitecXL as HTF, respectively $43.6 \%$ and $44.3 \%$, while yields are lower 233 for Solar Salt, $37.6 \%$. These differences will be explained in the following sections.

\section{3.3. Annual thermal power freeze protection}

235 Annual thermal power freeze protection is one of the values provided in the SAM's summary 236 table. It represents the thermal energy required to heat the storage system as well as the solar 237 field, to always ensure the safe temperature range of the HTF. In this way, the amount of thermal 238 energy required to heat the plant with the different HTF is presented in Table 5. 


\begin{tabular}{c|ccc}
\hline & Therminol VP-1 & Solar Salt & HitecXL \\
& (TES with HitecXL) & \\
\hline TES freeze protection $\left[\mathrm{MW}_{\mathrm{th}} \mathrm{h}\right]$ & 3.93 & 16.23 & 0.14 \\
Solar field freeze protection $\left[\mathrm{MW}_{\mathrm{th}} \mathrm{h}\right]$ & 0 & $36,452.05$ & $3,178.25$ \\
Annual total freeze protection $\left[\mathrm{MW}_{\mathrm{th}} \mathrm{h}\right]$ & 3.93 & $36,468.28$ & $3,178.39$ \\
\hline
\end{tabular}

240 Solar Salt presents the highest needs for freeze protection $\left(\sim 36,468 \mathrm{MW}_{\mathrm{th}} \mathrm{h}\right.$ in total) because its

241 melting point is very high $\left(220^{\circ} \mathrm{C}\right)$ and thus it requires maintaining the tanks at relatively high

242 temperatures - above $250{ }^{\circ} \mathrm{C}$. HitecXL also needs solar field freeze protection to avoid

243 solidification, but the amount of energy is much lower $(\sim 3,178 \mathrm{MWh})$. In the tanks, freeze

244 protection is almost insignificant because tanks have greater thermal inertia. Figure 1 allows to

245 analyze in more detail the needs for solar field heating according to the HTF used.

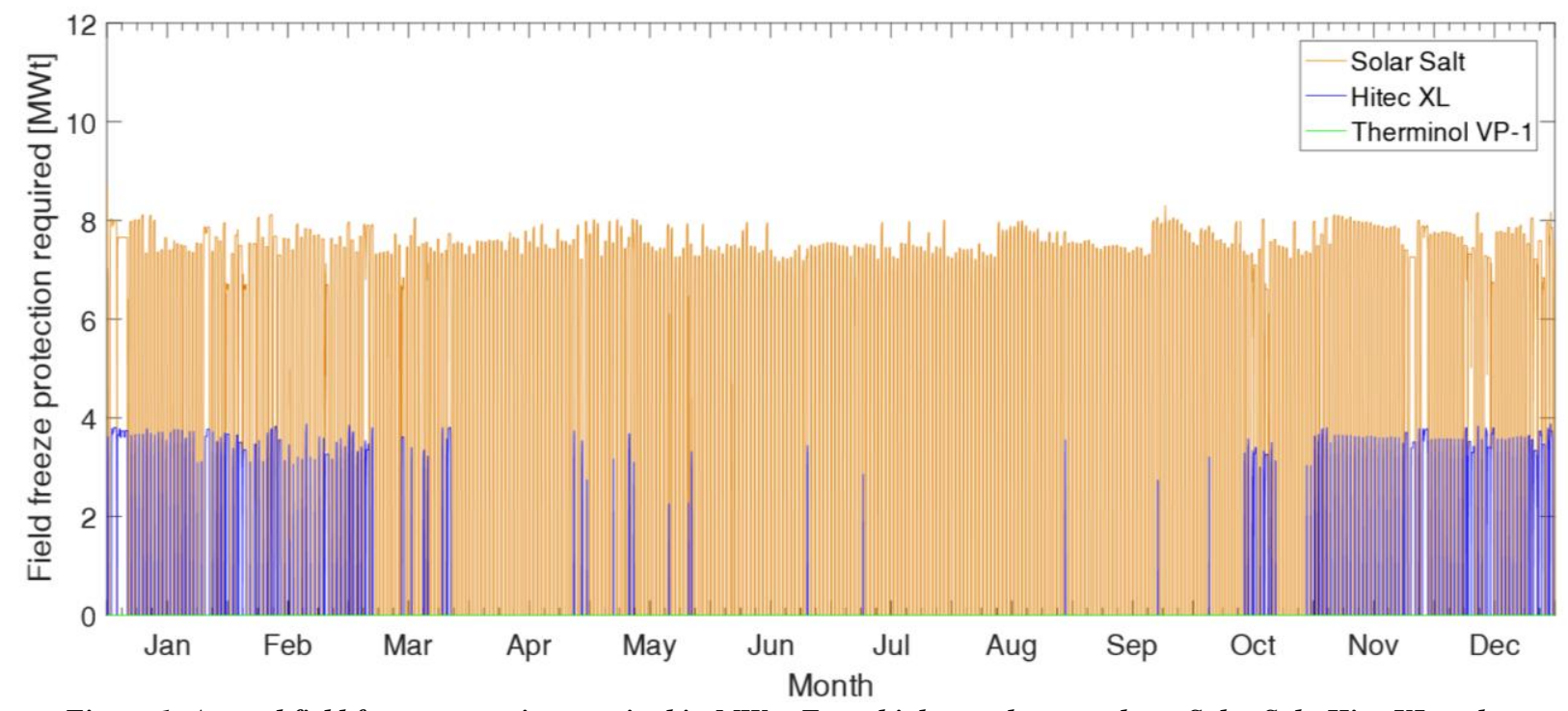

Figure 1: Annual field freeze protection required in MW ${ }_{\text {th. }}$ From highest to lowest values: Solar Salt, HitecXL and Therminol VP-1. 
249 With Solar Salt as HTF, up to $8.72 \mathrm{MW}_{\text {th }}$ are required during all the nights to avoid freezing,

250 while with HitecXL, a maximum value of $3.88 \mathrm{MW}_{\text {th }}$ is required only during moments of low

251 solar availability (typically winter). Therminol VP-1 implies the use of electrical heat tracing in

252 very particular cases and with very low power $\left(<0.01 \mathrm{MW}_{\text {th }}\right)$. Thus, it can be clearly seen that

253 using MS as HTF implies the substantial consumption of energy to maintain the HTF liquid,

254 which is an important drawback of MS when compared to TO. However, using a low melting-

255 point MS such as HitecXL (instead of Solar Salt) enables to divide the annual freeze protection

256 energy by a factor of 12.

\section{3.3. Pumping consumption}

258 In a conventional PT power plant, circulation of HTF and storage fluid are performed with 259 different pumping system: one pump circulates the HTF in the solar field, one circulates the HTF 260 through the heat exchanger of the TES system during discharge and two pumps circulate the 261 storage fluid from one tank to the other (one pump in each tank, plus back-up pumps). In a 262 similar plant with MS as HTF and storage fluid (direct storage), only two pumps are used: one in 263 the cold tank enables the circulation through the solar field, and one in the hot tank circulates the 264 HTF to the steam generator. In SAM's results, electricity consumption is divided between solar 265 field HTF pump and the others (the three pumps for indirect storage, and the hot tank pump for 266 direct storage). For the present simulation, electricity consumptions of those circulation systems 267 are gathered in Table 6. 


\section{Therminol VP-1 Solar Salt HitecXL}

\begin{tabular}{c|ccc}
\hline Parasitic power TES and Cycle HTF pump $\left[\mathrm{MW}_{\mathrm{e}} \mathrm{h}\right]$ & $2,241.41$ & $1,765.83$ & $1,760.29$ \\
Parasitic power solar field HTF pump $\left[\mathrm{MW}_{\mathrm{e}} \mathrm{h}\right]$ & $2,994.89$ & 411.83 & 697.06 \\
\hline Total $[\mathrm{MW} \mathrm{e}]$ & $5,236.30$ & $2,177.66$ & $2,457.35$ \\
\hline
\end{tabular}

269 It can be verified that TO is the HTF that leads to the highest electricity consumption, with a 270 total value of $\sim 5.2 \mathrm{GW}_{\mathrm{e}} \mathrm{h} v s . \sim 2.2-2.5 \mathrm{GW}_{\mathrm{e}} \mathrm{h}$ for MS. MS have lower pump consumptions thanks 271 to their higher operating temperatures, for the same low operating temperature, $\sim 290{ }^{\circ} \mathrm{C}$, 272 allowing circulation at lower flow rates and thus resulting in lower pressure drops. This 273 consumption varies along the year, as it is illustrated in Figure 2 and Figure 3.

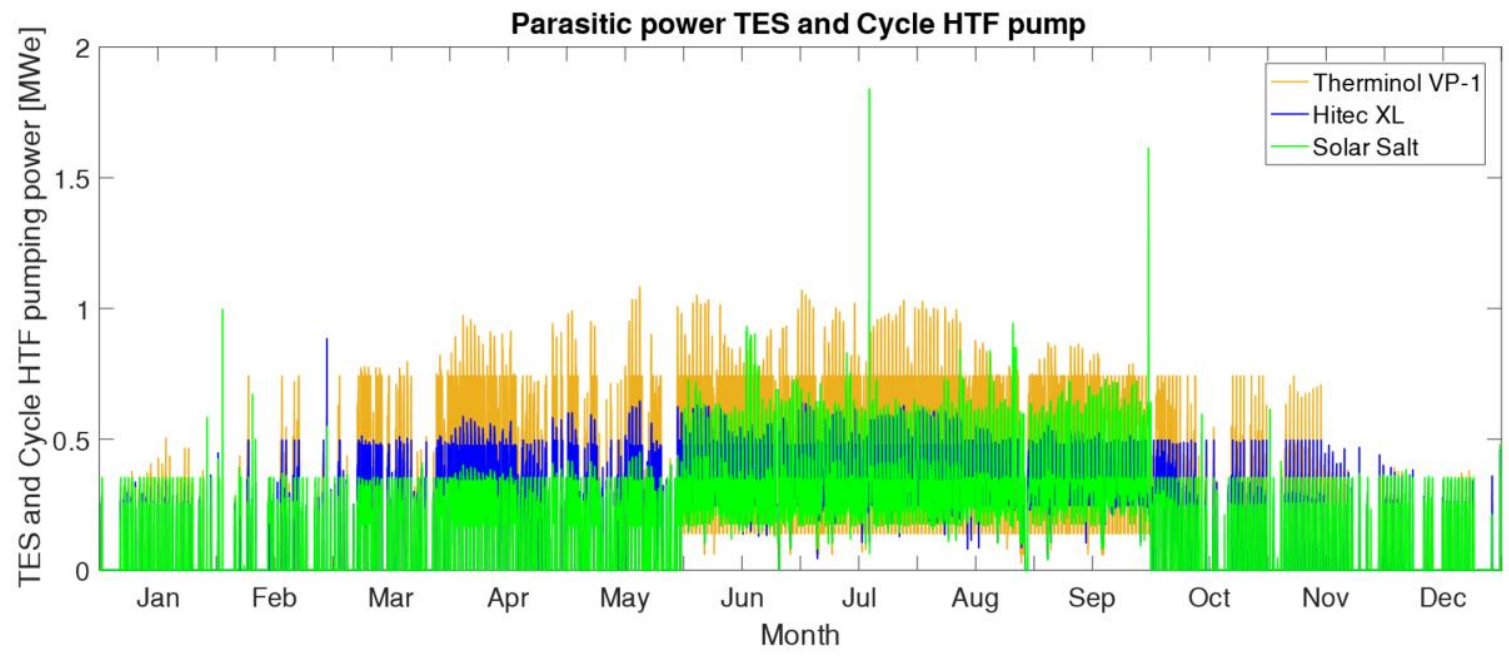

Figure 2: Parasitic power - TES and Cycle HTF pump. 


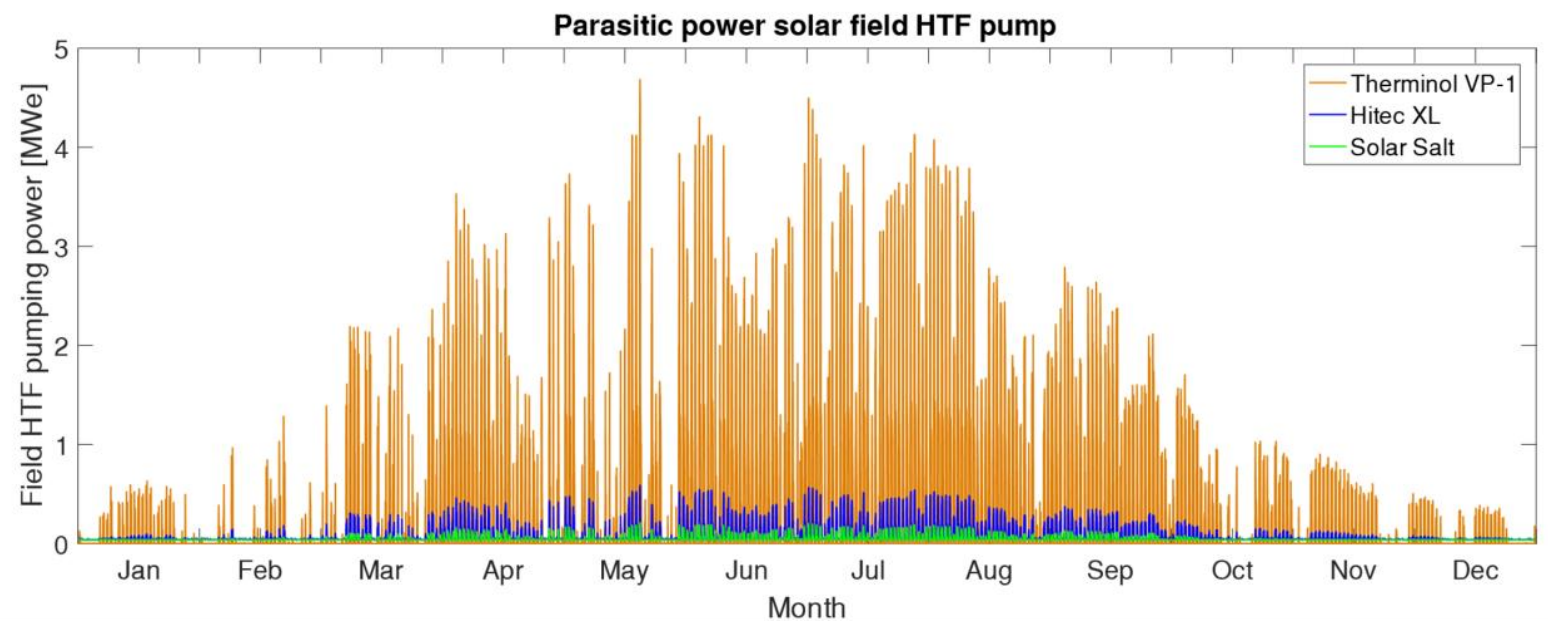

Figure 3: Parasitic power - solar field pump.

279 During months with the highest solar energy availability, typically summer, HTF is circulated

280 with the highest mass flows and solar field pumping power for TO reaches up to $4.68 \mathrm{MW}_{\mathrm{e}}$ for

281 the solar field pump and $\sim 1.01 \mathrm{MW}_{\mathrm{e}}$ for the other pumps. With MS, pumping consumption is

282 considerably reduced, with maximum values around $0.21 \mathrm{MW}_{\mathrm{e}}$ and $0.59 \mathrm{MW}_{\mathrm{e}}$, respectively. Of

283 the two salts, Solar Salt is the one that needs less pumping energy, mainly because its maximum

284 operating temperature is higher than that of HitecXL and its viscosity is lower.

285 3.4. Annual electricity consumption, night operation strategy and cost 286 estimate

287 The annual electricity consumption comprises the annual thermal freeze protection (considering 288 an electrical efficiency of 1), the pumping consumption and other consumers, such as auxiliary 289 heater operation, condenser operation (dry cooling), collector drive motors and other parasitic 290 consumptions that are all gathered in one block in Table 7. 


\begin{tabular}{c|ccc}
\hline & Therminol VP-1 & Solar Salt & HitecXL \\
\hline Thermal freeze protection $\left[\mathrm{MW}_{\mathrm{e}} \mathrm{h}\right]$ & 3.93 & $36,468.28$ & $3,178.39$ \\
Pumping $[\mathrm{MW} \mathrm{e}]$ & $5,236.30$ & $2,177.66$ & $2,457.35$ \\
Other parasitics (condenser, collector drive, etc.) & & & $11,171.01$ \\
{$\left[\mathrm{MW}_{\mathrm{e}} \mathrm{h}\right]$} & $11,681.26$ & $10,361.42$ & \\
\hline Total annual electricity consumption $\left[\mathrm{MW}_{\mathrm{e}} \mathrm{h}\right]$ & $16,921.49$ & $49,007.36$ & $16,806.75$ \\
\hline
\end{tabular}

292 The global analysis shows that there is a great discrepancy between electricity consumption with 293 Solar Salt, i.e. 49,007 MW $\mathrm{e}$, and those of the two other HTF that are quite akin: 16,807 MWh 294 for HitecXL and 16,921 MWh for Therminol VP-1. However, this is the worst-case scenario, in 295 which no specific operation strategy is considered. For example, the circulation of MS from the 296 cold tank through the piping during the night is not scrutinized, and it can significantly reduce 297 the amount of electricity spent on solar field heating.

298 Indeed, analyzing the meteorological data considered in this work, and using the assumption that 299 a day with insufficient solar resource is a day during which the plant produces less energy than 300 one hour of production at nominal power (i.e. $\sim 380 \mathrm{MW}_{\text {th }}$ ), 51 days a year with insufficient 301 solar resource are obtained, including:

$302-22$ periods with only 1 day (2 nights).

$303-8$ periods with 2 consecutive days (3 nights).

$304-3$ periods with 3 consecutive days (4 nights).

$305 \quad-1$ period with 4 consecutive days (5 nights).

306 The thermal inertia capacity of the cold tank is the energy that can be lost by the tank without 307 any risk of salt solidification. For Solar Salt, it is the energy lost by the fluid when cooling down 
308 from $290{ }^{\circ} \mathrm{C}$ to its minimum safety temperature, $250{ }^{\circ} \mathrm{C}$, resulting in $139.32 \mathrm{MW}_{\text {th }} \mathrm{h}$. For

309 HitecXL, it is the energy contained by the fluid between $290{ }^{\circ} \mathrm{C}$ and $170{ }^{\circ} \mathrm{C}$, i.e. $547.34 \mathrm{MW}_{\text {th }} \mathrm{h}$.

310 Considering total heat losses of $8.72 \mathrm{MW}_{\text {th }}$ with Solar Salt (worst case scenario), it means that

311 the tank can maintain the system heated at least 16 hours since heat losses will decrease with the

312 decreasing temperature. In the case of HitecXL, considering total heat losses of $3.88 \mathrm{MW}_{\text {th }}$, the

313 tank can maintain the system heated during $~ 141$ hours. It means that the use of the heat tracing

314 system can be totally avoided, this justifies the interest for this MS to be used as HTF. In fact,

315 considering the annual consumptions and that electricity has an estimated cost of $0.192 € / \mathrm{kWh}$, a

316 guess of annual electricity costs for the different HTF and the different scenarios is illustrated in

$317 \quad$ Table 8.

Table 8: Estimation annual electricity costs with each HTF.

\section{Therminol VP-1 Solar Salt HitecXL}

Base case annual electricity costs $[€]$

Cold tank to maintain the system heated

during periods with no solar radiation $[€]$

$\begin{array}{lll}3,248,926 & 9,409,413 & 3,226,896 \\ 3,248,926 & 4,229,076 & 2,616,645\end{array}$

$3,248,926-4,229,076-2,616,645$

319 Even without considering any further operating strategy to reduce electricity consumption for

320 solar field heating, HitecXL leads to lower electricity consumption than Therminol VP1. As

321 HitecXL has a relatively low melting point compared to Solar Salt, the electricity consumption

322 saved in the pumps is greater than the needed for heating (when compared to TO). On the other

323 hand, the total electrical consumption when using Solar Salt is approximately 3 times higher than

324 the consumption with the other two fluids which represents a significant increase in operational

325 expenditures (OPEX) of such a plant. Complementary, with the operation strategy that was

326 previously discussed, electricity spending would be avoided for the case of HitecXL and 
327 significantly lowered for the case of Solar Salt, however, net production would be lowered in 328 both cases. One may also note that, in terms of exergy, it is much more interesting to use thermal 329 power to heat the piping systems than electricity.

\section{3.5. LCOE calculation}

331 The LCOE (Levelized Cost of Energy) of a direct storage plant with MS is compared with the 332 one of a $50 \mathrm{MW}_{\mathrm{e}}$ conventional plant, based on reference costs (CAPEX and OPEX) from 333 literature [23, 5, 24], and some calculations that are based on information obtained from HPS2

334 partners. The costs of HTF correspond to those from [5]. The energy spent in the pumping of the 335 fluid in the solar field and the value of heat losses are obtained through SAM's results. The 336 power block efficiency is calculated using Equation (9) and assuming an exergy efficiency of 3370.7 for both cases, see Equation (10).

$$
\eta_{P B}=\eta_{\text {ex }} \cdot \eta_{\text {Carnot }}
$$

338 with,

$$
\eta_{\text {ex }}=0.7 ; \eta_{\text {Carnot }}=1-\frac{T_{C S}}{T_{H S}}
$$

339 Where $\mathrm{T}_{\mathrm{CS}}$ corresponds to the cold source temperature (ambient) and $\mathrm{T}_{\mathrm{HS}}$ to the hot source 340 temperature (in K). All the cost and performance details are given in Table 9. 
Table 9: Costs of conventional power plant and direct storage with molten salts plant.

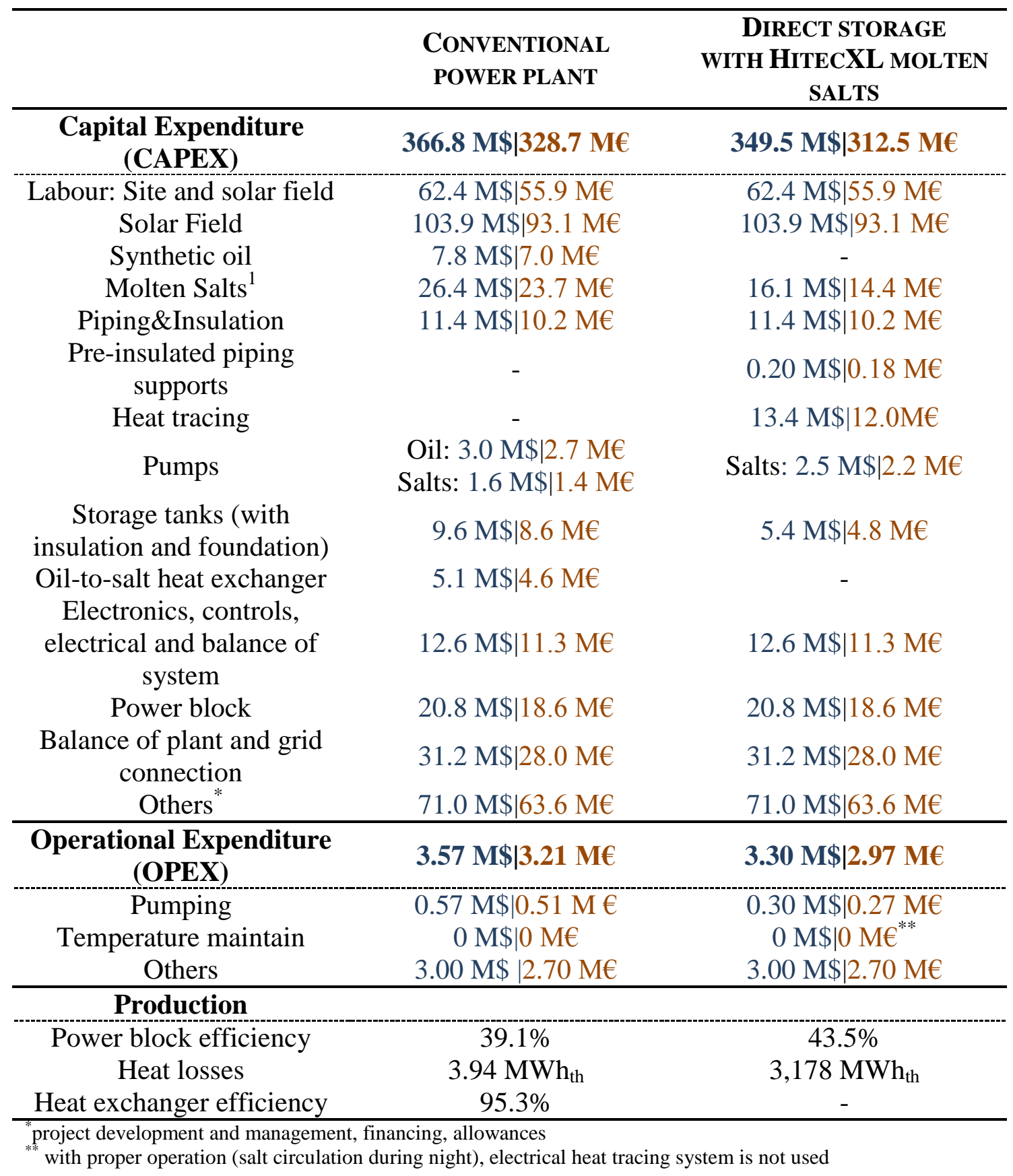

342 Two different methods were used to calculate LCOE of the two plant types. The first one using

343 SAM, in the CSP parabolic trough model - LCOE calculator, and a second method using

344 algebraic calculations. For both cases, an operating period of 25 years was considered [25].

${ }^{1}$ In this value are included the cost of salts necessary for the storage in the case of conventional plant and for the storage and HTF in the case of direct storage with molten salts plant. 
345 First method: this method uses SAM to calculate the LCOE, inserting CAPEX and OPEX that 346 are reported in Table 9. The obtained results are presented in Table $\mathbf{1 0 .}$

Table 10: LCOE values obtained through the simulations in SAM.

\begin{tabular}{c|cccc}
\hline & $\begin{array}{c}\text { CAPEX } \\
{[\mathrm{M} \$] /[\mathrm{M} €]}\end{array}$ & $\begin{array}{c}\text { OPEX } \\
{[\mathrm{M} \$] /[\mathrm{M} €]}\end{array}$ & $\begin{array}{c}\text { Annual } \\
\text { electricity } \\
\text { (produced }) \\
{\left[\mathrm{MW}_{\mathrm{e}}\right]}\end{array}$ & $\begin{array}{c}\mathrm{LCOE} \\
[\mathrm{c} \$ / \mathrm{kWh}] / \mathrm{c} € / \mathrm{kWh}]^{2}\end{array}$ \\
\cline { 2 - 5 } $\begin{array}{c}\text { Conventional CSP } \\
\text { power plant }\end{array}$ & $366.80 / 328.7$ & $3.57 / 3.21$ & 191,043 & $17.69 / 15.80$ \\
$\begin{array}{c}\text { Direct storage with } \\
\text { molten salts } \\
\text { (HitecXL) }\end{array}$ & $349.48 / 312.47$ & $3.30 / 2.97$ & 194,169 & $16.57 / 14.80$ \\
\hline
\end{tabular}

348 It can be verified that despite the extra anti-freezing protection requirements for the use of MS as 349 HTF (namely electrical heat tracing, impedance heating and pre-insulated piping supports), the 350 CAPEX value of this type of plant is lower. This is due to the savings in:

$351 \quad-\quad$ synthetic oil acquisition;

352 - storage tanks size and quantity of MS, thanks to larger operating temperature as 353 compared with TO;

$354 \quad$ - number of pumps and heat exchangers, because there is only one working fluid when MS 355 is circulated in both the solar field and TES and, thus, a single system pump (plus a back356 up one).

357 Therefore, as previously shown in Table 9, CAPEX and OPEX are lower for HitecXL than for 358 TO. Besides, thanks to the higher operating temperature and, hence, higher power block 359 efficiency, a greater annual electricity production is found with HitecXL, leading to a reduction 360 of the LCOE by about $6.3 \%$ when compared to the case with TO.

${ }^{2}$ Conversion rate: 1 EUR $=1,11844$ USD $\mid 1$ USD $=0,894103$ EUR 
Second method: LCOE calculation are made using the values in Table 9, in Euros, considering

362 a discount rate of $2 \%$ (value of the Portuguese rate, the electricity production values obtained

363 through the SAM's simulation for Évora and considering a decrease in the plant efficiency along

364 time (0.8\%/year), due to ageing components. In these calculations the value of the energy

365 consumed to heat the solar field when using MS is discounted from the total value of produced

366 energy. In addition, the degradation of the TO that occurs in conventional plants is also taken

367 into account [26]. As such, the cost of oil exchanges every 5 years has been included in the

368 OPEX. Considering the Equation (11) to calculate the LCOE value:

369 whereby,

$$
L C O E=\frac{\sum_{n_{y}=0}^{N} C_{n_{y}}(1+r)^{-n_{y}}}{\sum_{n_{y}=1}^{N} E_{n_{y}}(1+r)^{-n_{y}}},
$$

- $\quad C_{n_{y}}$ - total cost, CAPEX and/or OPEX, for year $n_{y}$;

- $E_{n_{y}}-$ annual electricity production $(\mathrm{kWh})$ for year $n_{y}$;

- $\quad N$ - lifespan;

- $\quad r$-discount rate.

374 The values obtained through the calculation are presented in the Table 11

Table 11: LCOE values obtained through the second approach.

\begin{tabular}{c|cccc}
\hline & $\begin{array}{c}\text { CAPEX } \\
{[\mathrm{M} \$] /[\mathrm{M} €]}\end{array}$ & $\begin{array}{c}\text { OPEX } \\
{[\mathrm{M} \$] /[\mathrm{M} €]}\end{array}$ & $\begin{array}{c}\text { Annual } \\
\text { electricity } \\
\text { (produced) } \\
{\left[\mathrm{MW}_{\mathrm{e}}\right]}\end{array}$ & $\begin{array}{c}\mathrm{LCOE} \\
{[\mathrm{c} \$ / \mathrm{kWh}] /[\mathrm{c} € / \mathrm{kWh}]}\end{array}$ \\
\cline { 2 - 5 } $\begin{array}{c}\text { Conventional } \\
\text { power plant }\end{array}$ & $366.80 / 328.7$ & $3.57 / 3.21$ & 191,043 & $14.54 / 13.00$ \\
$\begin{array}{c}\text { Direct storage } \\
\text { with HitecXL }\end{array}$ & $349.48 / 312.47$ & $3.30 / 2.97$ & 190,526 & $12.85 / 11.49$ \\
\hline
\end{tabular}

376 A reduction of $11.6 \%$ in the LCOE value is estimated using HitecXL instead of Therminol VP-1

377 as HTF. This reduction is lower than the value envisaged by Kearney et al. [5], 17.6\%, because 
378 of all the extra costs that are considered in the present study (pre-insulated piping supports, heat 379 tracing, etc.) and could be even lower because of more expensive (currently 25\%) high 380 temperature, corrosion resistant receivers.

381 With Solar Salt, LCOE estimated with both methods are higher than with TO, $38216.02 \mathrm{c} € / \mathrm{kWh}-16.98 \mathrm{c} € / \mathrm{kWh}$, because of the substantial needs of electricity to maintain the salt 383 above its minimum safe temperature (see Appendix 6).

384 One may note that all LCOE values should be lower since a large part of the costs presented in

385 Table 9 was obtained from references already a few years old [23, 5, 24], from which data is 386 available. In fact, LCOE of current project in Middle East and Morocco are about 7-10 c\$/ kWh, 387 however details are not available. Nevertheless, it is expected that a comparison between the two 388 fluids with up-dated costs would certainly show the same potential cost reduction running 389 HitecXL as HTF.

390 4. Power block design with higher $\boldsymbol{T}_{H S}$ and greater $\Delta T$

391 As MS allow to reach higher $T_{H S}$, the corresponding power cycles inherently have higher 392 theoretical efficiencies, $c f$. Equation (10). Considering a cold source temperature $\mathrm{T}_{\mathrm{CS}}$ of $20{ }^{\circ} \mathrm{C}$ 393 (ambient), the maximum efficiencies that the cycles can achieve are 62\% with HitecXL $394\left(\mathrm{~T}_{\mathrm{HS}}=500{ }^{\circ} \mathrm{C}\right)$ and $65 \%$ with Solar Salt $\left(\mathrm{T}_{\mathrm{HS}}=565^{\circ} \mathrm{C}\right)$, vs. $56 \%$ for $\mathrm{TO}\left(\mathrm{T}_{\mathrm{HS}}=400{ }^{\circ} \mathrm{C}\right)$. 395 However, the actual machines, that follow the Rankine cycle, are hardly close to the ideal ones, 396 reaching 70\% exergy efficiency, $c f$. Equation (9), at the cost of high complexity and CAPEX. 397 In the case of the plants working at $400{ }^{\circ} \mathrm{C}$, this complexity is required to counterbalance the 398 relatively low Carnot efficiency. In the case of MS power plants working at $T_{H S}>500{ }^{\circ} \mathrm{C}$, it 399 might be interesting to create simpler and consequently more cost-effective thermodynamic 
400 cycles while attaining similar performances to those working at $400{ }^{\circ} \mathrm{C}$. Concomitantly, this 401 section presents an assessment of power cycle efficiencies that can be expected for various 402 configurations. The results are compared to the efficiency of the cycle that is used in commercial $40350 \mathrm{MW}_{\mathrm{e}}$ power plants, like Andasol 3, as described by Ascensión Piquer et al. [27] and using a 404 similar methodology.

\section{4.1. Power cycle of a molten salt plant with direct storage}

406 With the purpose of emphasizing the relation between the complexity of the cycle and its

407 efficiency, the MS plant power block efficiency was assessed for: 1) basic cycle; 2) cycle with 408 reheating; 3) cycle with various bleedings; 4) a complete cycle with reheating and six bleedings.

409 Several assumptions were made to perform such assessment:

410 - Water is compressed up to a pressure of 150 bars in the case of HitecXL and 165 bars in 411 the case of Solar Salt.

412 - In the steam generator, water is vaporized with a 15 bars pressure drop, then superheated 413 up to $490{ }^{\circ} \mathrm{C}$ (HitecXL) or $555^{\circ} \mathrm{C}$ (Solar Salt), with $10 \mathrm{~K}$ pinch between MS and steam.

414 - Superheated high pressure steam is expanded in a multi-stage turbine with one reheating 415 (pressure drops: 2 bars) and six bleedings. The different bleedings are used to preheat the 416 water through opened and closed feedwater tanks. Turbine is adiabatic and has an 417 isentropic efficiency of $\eta_{T}=0.87$. The steam quality at the turbine outlet must be higher 418 than $95 \%$ to avoid corrosion and/or cavitation.

419 - Steam is condensed with a low pressure of 0.06 bars and a temperature of $36{ }^{\circ} \mathrm{C}$, then $420 \quad$ compressed again. 
- The mass flows are determined according to the system conditions and from energy balance conditions.

423 The values of pressure, temperature, mass flow and enthalpy at each point marked on 424 Temperature-Entropy (T-S) diagram of the cycles, Figure 4 and Figure 5, are given in tables 425 available on Appendixes 2 to 5. The cycle efficiencies are calculated from the output work of 426 the turbine stage(s) $\dot{W}_{\text {turbine,1 }}$ and $\dot{W}_{\text {turbine, } 2}$, the electrical consumption of the pump(s) $427 \dot{W}_{\text {pump,1 }}$ and $\dot{W}_{\text {pump,2 }}$ and the input heat(s) of the steam generator $\dot{Q}_{\text {heat,1 }}$ (main heating) and $428 \dot{Q}_{\text {heat,2 }}$ (reheating), using Equation (12).

$$
\eta_{\text {cycle }}=\frac{\dot{W}_{\text {turbine }, 1}+\dot{W}_{\text {turbine }, 2}-\dot{W}_{\text {pump }, 1}-\dot{W}_{\text {pump }, 2}}{\dot{Q}_{\text {heat }, 1}+\dot{Q}_{\text {heat }, 2}}
$$

\section{4.2. Cycle efficiency with reheating and one bleeding at $290{ }^{\circ} \mathrm{C}$ (Solar Salt) or $430 \quad 200{ }^{\circ} \mathbf{C}($ HitecXL)}

431 The first cycle that is considered is a relatively simple one, with the main objective of preventing

432 salt solidification within the steam generator, thanks to one steam bleeding. In the case of Solar

433 Salt, a steam bleeding at 74.36 bars results on a water saturation temperature of $290{ }^{\circ} \mathrm{C}$ which

434 allows to heat liquid water to that temperature before entering the steam generator. In the cycle 435 with a bleeding at $290{ }^{\circ} \mathrm{C}$, represented in Figure 4 by a green line, a mixer is used at point 7 . Its 436 use allows a heat exchange with $100 \%$ efficiency, although it implies adding a new pump (from 437 point 7 to point 9$)$. 


\section{T-S diagram, Water}

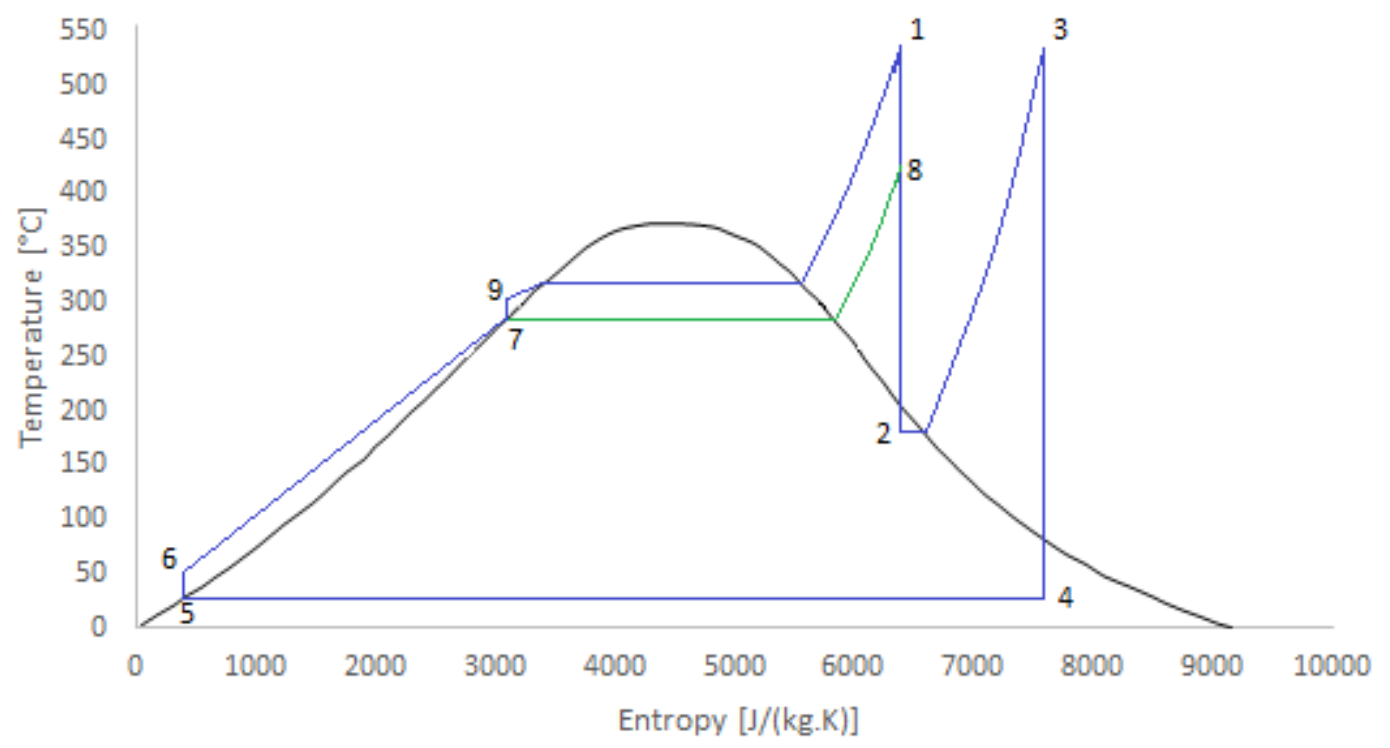

Figure 4: Rankine cycle with reheating and one bleeding at $290{ }^{\circ} \mathrm{C}$. See Appendix 2 for data and details.

440 The bleeding not only solves the problem of high melting point of salts, raising the water 441 temperature from $37.95{ }^{\circ} \mathrm{C}$ to $290{ }^{\circ} \mathrm{C}$, but also increases the cycle efficiency from $39.86 \%$ to $44241.67 \%$.

443 For the second MS, HitecXL, since the safety temperature is $170{ }^{\circ} \mathrm{C}$, it is possible to use a cycle 444 with a single bleeding at $200{ }^{\circ} \mathrm{C}(15.54$ bars) to prevent solidification. In this case, a power block 445 efficiency of $41.04 \%$ is found.

\section{4.3. Complete cycle with HitecXL}

447 As previously mentioned, bleedings are normally used to improve cycle efficiency through 448 increases of water temperature before entering the steam generator. In this way, the complete 449 cycle of a conventional plant (with reheating and six bleedings), adapted to the pressure and 450 temperature conditions of a plant using MS (namely HitecXL) as HTF, is illustrated in Figure 5. 


\section{T-S diagram, Water}

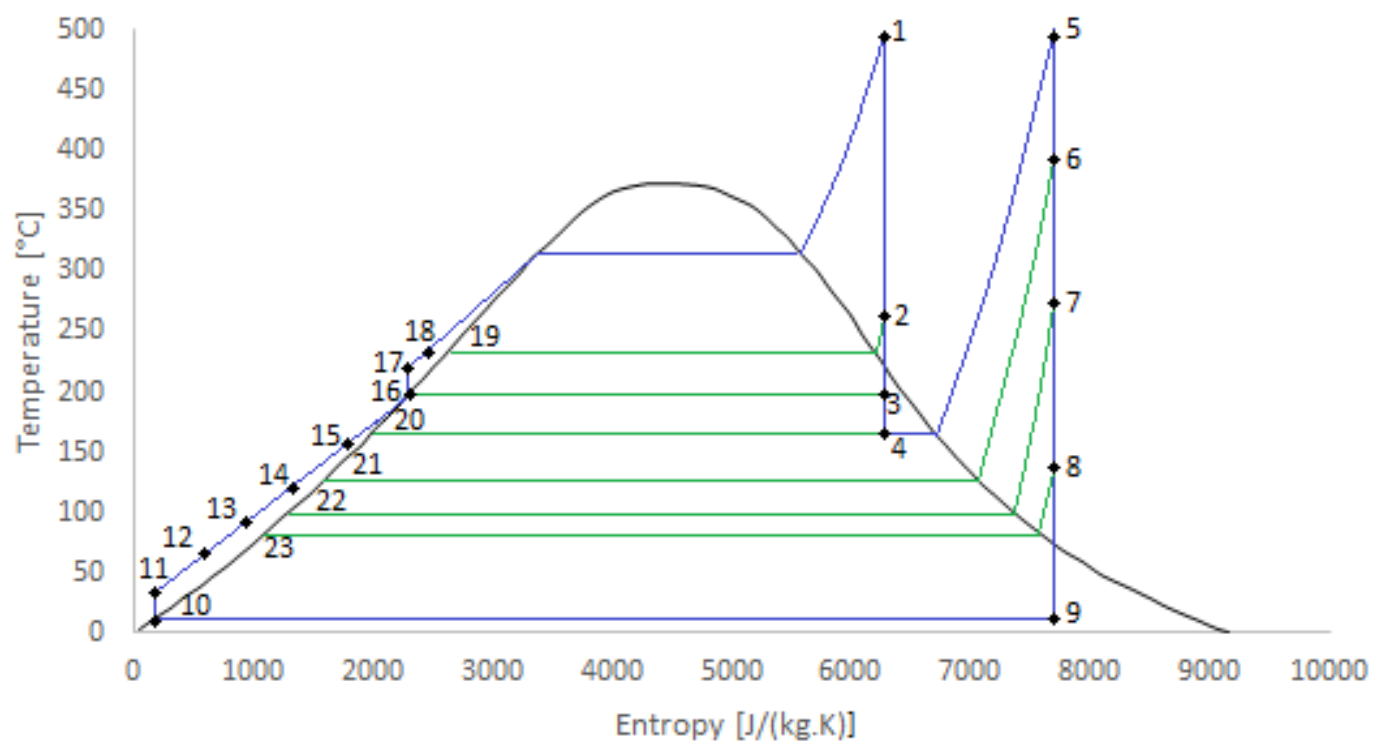

453 For this complete cycle, the calculation details of the power block efficiency are given by 454 Equation (12) and Equations (13) to (18).

455 1) The work carried out by the high-pressure turbine (turbine 1) and the low-pressure $456 \quad$ turbine (turbine 2).

$$
\begin{aligned}
\dot{W}_{\text {turbine }, 1}= & \dot{m}_{1 \rightarrow 2}\left(h_{1}-h_{2}\right)+\dot{m}_{2 \rightarrow 3}\left(h_{2}-h_{3}\right)+\dot{m}_{3 \rightarrow 4}\left(h_{3}-h_{4}\right) \\
& =21,669 \mathrm{~kW}, \\
\dot{W}_{\text {turbine }, 2} & \\
& =\dot{m}_{5 \rightarrow 6}\left(h_{5}-h_{6}\right)+\dot{m}_{6 \rightarrow 7}\left(h_{6}-h_{7}\right)+\dot{m}_{7 \rightarrow 8}\left(h_{7}-h_{8}\right) \\
& +\dot{m}_{8 \rightarrow 9}\left(h_{8}-h_{9}\right)=28,331 \mathrm{~kW} .
\end{aligned}
$$

457 2) The work done by the two pumps (pump 1 and pump 2).

$$
\begin{aligned}
& \dot{W}_{\text {pump }, 1}=\dot{m}_{10 \rightarrow 11}\left(h_{11}-h_{10}\right)=53 \mathrm{~kW} \\
& \dot{W}_{\text {pump }, 2}=\dot{m}_{16 \rightarrow 17}\left(h_{17}-h_{16}\right)=479 \mathrm{~kW} .
\end{aligned}
$$

$4583)$ And the thermal power that is needed for heating $\left(\dot{Q}_{\text {heat }, 1}\right)$ and reheating $\left(\dot{Q}_{\text {heat }, 2}\right)$.

$$
\dot{Q}_{\text {heat }, 1}=\dot{m}_{18 \rightarrow 1}\left(h_{1}-h_{18}\right)=93,439 \mathrm{~kW} \text {, }
$$




$$
\dot{Q}_{\text {heat }, 2}=\dot{m}_{4 \rightarrow 5}\left(h_{5}-h_{4}\right)=22,880 \mathrm{~kW} .
$$

459 The obtained efficiency value, $42.53 \%$, is much higher than the one for the complete cycle of a 460 conventional plant, $\sim 39.78 \%$ [27]. This increase represents a significant value in the annual

461 production of a plant. Similar procedure is performed for a complete cycle of a Solar Salt plant 462 and all the results are presented in the next section.

\section{4.4. Comparative analysis between the three cycles}

464 In order to visualize with better strictness the differences between the various cycles of the two 465 types of plants with the three different fluids, Table 12 illustrates the efficiencies of all the

466 different power cycles that were considered, calculated with Equation (12). Corresponding 467 exergy efficiencies can be found in Appendix 7. 


\begin{tabular}{c|c|c|c}
\cline { 2 - 3 } & $\begin{array}{c}\text { Conventional } \\
\text { plant } \\
\eta_{\text {cycle }}\end{array}$ & $\begin{array}{c}\text { Direct storage } \\
\text { HitecXL } \\
\eta_{\text {cycle }}\end{array}$ & $\begin{array}{c}\text { Direct storage } \\
\text { Solar Salt } \\
\eta_{\text {cycle }}\end{array}$ \\
\hline Cycle w/ reheating & $13.80 \%$ & $21.29 \%$ & $22.89 \%$ \\
Cycle w/ reheating and one bleeding & $35.85 \%$ & $38.11 \%$ & $39.86 \%$ \\
Cycle w/ reheating and two bleedings & $37.27 \%$ & $41.04 \%$ & $41.67 \%$ \\
Cycle w/ reheating and three bleedings & $38.01 \%$ & $42.05 \%$ & $43.53 \%$ \\
Cycle w/ reheating and four bleedings & $38.45 \%$ & $42.14 \%$ & $43.82 \%$ \\
Cycle w/ reheating and five bleedings & $39.03 \%$ & $42.20 \%$ & $44.07 \%$ \\
\hline Complete cycle & $39.78 \%$ & $42.53 \%$ & $44.58 \%$ \\
\hline
\end{tabular}

469 Results of Table 12 can be analysed in two ways. The first is that the use of MS as HTF allows

470 the achievement of simpler/cheaper power blocks, for example, single bleeding and one reheat,

471 avoiding salt solidification while still having better efficiencies than the complete cycle of a 472 conventional plant with TO as HTF (six bleedings and one reheat): $41.04 \%-41.67 \%$ vs.

$473 \quad 39.78 \%$. The second way is that with the same complexity, i.e., the same initial investment, a 474 higher efficiency is achieved: $42.53 \%$ with HitecXL, and $44.58 \%$ with Solar Salt as compared 475 with $39.78 \%$ for TO. This choice between one or several bleedings will depend on the 476 investment capacity.

\section{5. Conclusions and future perspectives}

478 In the present work, it has been shown that using MS as HTF instead of TO implies:

479 - No risk of bending of the absorber tubes thanks to remaining very high Reynolds number 480 (> 60,000, knowing that minimum allowed values by manufacturer is 20,000$)$. 
- $30 \%$ lower heat transfer coefficient within the receivers tubes, although those coefficients are still very high $\left(>3500 \mathrm{~W} \cdot \mathrm{m}^{-2} \cdot \mathrm{K}^{-1}\right)$, and heat transfer performance reduction should be negligible.

- $68 \%$ (HitecXL) to $84 \%$ (Solar Salt) reduction of the pressure drops, thanks to a circulation at relatively low velocity due to the higher temperature difference that is experienced by MS relatively to TO. This result was not expected since MS are more

Results from simulation with SAM software confirmed that pressure drops were lower for MS, 489 and therefore pumping electricity consumption was larger to circulate TO. However, larger needs

490 for electricity to maintain MS above their freezing point were found, especially in the case of 491 Solar Salt. Nevertheless, is has been shown that TES systems generally have sufficient thermal 492 inertia capacity to maintain the whole solar field and interconnecting piping system at a 493 sufficient temperature throughout one to several days with insufficient solar irradiation.

494 In addition, LCOE estimation showed a potential decrease (>6\%) for power plants with 495 HitecXL, especially thanks to smaller TES tanks, no heat exchanger, cheaper HTF and higher 496 power block efficiency.

497 It has also been shown that instead of high-performance complex power blocks, it is possible to 498 install a simpler and cost-effective equipment with a theoretical efficiency that is still higher than 499 the conventional ones that are adapted to TO's temperature ranges.

500 Finally, the use of MS as HTF in a parabolic trough power plant implies extra care regarding 501 freezing protection. Building new linear-focusing systems with MS as HTF will require the 502 design of several components such as electrical heat tracing, impedance heating, pre-insulated 
503 piping supports, etc. Only experimental validation of the feasibility of operating such power

504 plants at relatively low cost will confirm the interest of using MS as both HTF and TES fluid.

\section{Acknowledgements}

506 This work was co-funded by the European Union through the European Regional Development

507 Fund, framed in COMPETE 2020 (Operational Programme Competitiveness and

508 Internationalization), through the ICT project (UID/GEO/04683/2013) with reference POCI-01-

509 0145-FEDER-007690. The authors acknowledge relevant discussions with Michael Wittman and

510 Klaus Hennecke (DLR), Mark and Kay Schmitz (TSK-FLAGSOL), Peter Schmidt (ELTHERM),

511 and Evaristo Esquinas (RIOGLASS). HGS is grateful to Francis Lopes (ICT) for processing the

512 meteorological data and to Samuel Bárias (ICT) and Jorge Neto (IPMA) for providing it.

\section{References}

[1] IEA, "Installed power generation capacity by source in the Stated Policies Scenario," IEA, 2000-2040. [Online]. Available: https://www.iea.org/data-and-statistics/charts/installedpower-generation-capacity-by-source-in-the-stated-policies-scenario-2000-2040.

[2] NREL, "National Renewable Energy Laboratory (NREL) Home Page | NREL," [Online]. Available: https://www.nrel.gov/.

[3] D. Baharoon, H. Rahman, W. Omar and S. Fadhl, "Historical Development of Concentrating Solar Power Technologies to Generate Clean Electricity Efficiently," Renewable and Sustainable Energy Reviews, vol. 41, pp. 996-1027, 2015.

[4] P. Gauché, J. Rudman, M. Mabaso, W. Landman , T. von Backstrom and A. Brent, "System value and progress of CSP," Solar Energy, vol. 152, pp. 106-139, 2017.

[5] D. Kearney, U. Herrmann, P. Nava, B. Kelly, R. Mahoney, J. Pacheco, R. Cable, N. Potrovitza, D. Blake and H. Price, "Assessment of a Molten Salt Heat Transfer Fluid in a Parabolic Trough Solar Field," Journal of Solar Energy Engineering, vol. 125, pp. 170-176, 2003.

[6] M. Wittmann, M. Schmitz, H. G. Silva, P. Schmidt, G. Doppelbauer, R. Ernst, P. Santamaria, T. Miltkau, D. Golovca, L. Pacheco, D. Hogemann, M. Meyer-Grunefeldt and B. Seubert, "HPS2 - Demonstration of a Molten-Salt in Parabolic Trough Plants - Design of Plant," SolarPaces, 
2018.

[7] A. Maccari, D. Bissi, G. Casubolo, F. Guerrini, L. Lucatello, G. Luna, A. Rivaben, E. Savoldi, S. Tamano and M. Zuanella, "Archimede Solar Energy Molten Salt Parabolic Trough Demo Plant: A Step Ahead towards the New Frontiers of CSP," Energy Procedia, vol. 69, pp. 1643$1651,2015$.

[8] K.Vignarooban, X. Xu, A. Arvay, K. Hsu and A. M. Kannan, "Heat transfer fluids for concentrating solar power systems - A review," Applied Energy, vol. 146, pp. 383-396, 2015.

[9] F. Casella, E. Casati and P. Colonna, "Optimal Operation of Solar Tower Plants with Thermal Storage for System Design," IFAC Proceedings Volumes, vol. 47, pp. 4972-4978, 2014.

[10] ENEA, "MATS Project - Multipurpose Applications by Thermodynamic Solar," [Online]. Available: http://www.mats.enea.it/. [Accessed 2019].

[11] A. Gil, M. Medrano, I. Martorell, A. Lázaro, P. Dolado and B. Zalba, "State of the art on high temperature thermal energy storage for power generation. Part 1 - Concepts, materials and modellization," Renewable and Sustainable Energy Reviews, pp. 31-55, 2010.

[12] T. Boukelia, O. Arslan and M. Mecibah, "Potential assessment of a parabolic trough solar thermal power plant considering hourly analysis: ANN-based approach," Renewable Energy, vol. 105, pp. 324-333, 2017.

[13] A. Bonk, S. Sau, N. Uranga, M. Hernaiz and T. Bauer, "Advanced heat transfer fluids for direct molten salt line-focusing CSP plants," Progress in Energy and Combustion Science, pp. 69-87, 2018.

[14] S. M. Akbarimoosavi and M. Yaghoubi, "3D Thermal-structural analysis of an absorber tube of a parabolic trough collector and the effect of tube deflection on optical efficiency," Energy Procedia, vol. 49, pp. 2433-2443, 2014.

[15] S. Khanna, V. Sharma, S. B. Kedare and S. Singh, "Experimental investigation of the bending of absorber tube of solar parabolic trough concentrator and comparison with analytical results," Solar Energy, vol. 125, pp. 1-11, 2016. 
[16] I. Tosun, Modeling in Transport Phenomena - A Conceptual Approach 2nd Edition, Turkey : Elsevier Science, 2007.

[17] NREL, "Technical Manual for the SAM Physical Trough Model," [Online]. Available: https://www.nrel.gov/docs/fy11osti/51825.pdf.

[18] N. Blair, A. Dobos, J. Freeman, T. Neises, M. Wagner and T. Ferguson, "System Advisor Model - General Description," National Renewable Energy Laboratory, Golden, C0,, 2014.

[19] NREL, "System Advisor Moldel (SAM)," [Online]. Available: https://sam.nrel.gov/download. [Accessed 2019].

[20] NREL, "Concentrating Solar Power Projects - Andasol-3," [Online]. Available: https://solarpaces.nrel.gov/andasol-3.

[21] F. Lopes, R. Conceição, T. Fasquelle, H. Silva, R. Salgado, P. Canhoto and M. CollaresPereira, "Predicted Direct Solar Radiation (ECMWF) for Optimized Operational Strategies of Linear Focus Parabolic-Trough Systems.," Renewable Energy, 2019.

[22] F. M. Lopes, R. Conceição, H. G. Silva, T. Fasquelle, R. Salgado, P. Canhoto and M. CollaresPereira, "Short-Term Forecasts of DNI from an Integrated Forecasting System (ECMWF) for Optimized Operational Strategies of a Central Receiver System," energies, vol. 12, no. 7, pp. 1368-1386, 2019.

[23] IRENA, "Renewable Energy Technologies: cost analysis series," 2012. [Online]. Available: https://www.irena.org/documentdownloads/publications/re_technologies_cost_analysiscsp.pdf.

[24] C. Turchi, M. Mehos, C. K. Ho and G. J. Kolb, "Current and future costs for parabolic trough and power tower systems in the US market," U.S.A, 2010.

[25] DLR, “Concentrating solar power now - clean energy for sustainable development," 2002.

[26] H. Grirate, N. Zari, A. Elmchaouri, S. Molina and R. Couturier, "Life Time Analysis of Thermal Oil Used as Heat Transfer Fluid in CSP Power Plant," AIP Conference Proceedings, 31 May 2016. 
[27] A. A. Piquer, "Determinación del ciclo de vapor de una central solar termoeléctrica CCP de 50MW," Universidad Carlos III de Madrid, Madrid, 2012.

[28] "International Energy Agency," [Online]. Available: https://www.iea.org. [Accessed 12 2018].

516 


\section{Appendices}

519

520

521

522

\begin{tabular}{|c|c|c|c|}
\hline Solar Field & Solar Field Parameters & $\begin{array}{c}\text { Row spacing }[\mathrm{m}] \\
\text { Piping thermal loss coefficient }\left[\mathrm{W} . \mathrm{m}^{-}\right. \\
\left.{ }^{1} \cdot \mathrm{K}^{-1}\right] \\
\text { Wind stow speed }\left[\mathrm{m} \cdot \mathrm{s}^{-1}\right]\end{array}$ & $\begin{array}{c}18.9 \\
0.85 / 0.68 / 0.65\end{array}$ \\
\hline & Heat Transfer Fluid & $\begin{array}{c}\text { Freeze protection temperature }\left[{ }^{\circ} \mathrm{C}\right] \\
\text { Min single loop flow rate }\left[\mathrm{kg} \cdot \mathrm{s}^{-1}\right] \\
\text { Max single loop flow rate }\left[\mathrm{kg} . \mathrm{s}^{-1}\right] \\
\text { Header design min flow velocity }\left[\mathrm{m} . \mathrm{s}^{-1}\right] \\
\text { Header design max flow velocity }\left[\mathrm{m} . \mathrm{s}^{-1}\right]\end{array}$ & $\begin{array}{c}43 / 170 / 250 \\
0.3 / 4 / 4 \\
12.4 / 12.7 / 9 \\
0.06 / 0.72 / 0.36 \\
3.47 / 1.33 / 0.96\end{array}$ \\
\hline
\end{tabular}

510120

7.5

Therminol VP-1/HitecXL/Solar Salt

290

$400 / 500 / 565$
Loop outlet HTF temperature $\left[{ }^{\circ} \mathrm{C}\right]$

\begin{tabular}{|c|c|c|}
\hline \multirow[t]{9}{*}{ Storage System } & Tank height $[\mathrm{m}]$ & 14 \\
\hline & Tank fluid minimum height $[\mathrm{m}]$ & 0.7 \\
\hline & Parallel tank pairs & 1 \\
\hline & Wetted loss coefficient $\left[\mathrm{W} \cdot \mathrm{m}^{-2} \cdot \mathrm{K}^{-1}\right]$ & 0.163 \\
\hline & Initial hot HTF percent & 0 \\
\hline & Cold tank heater temperature set point $\left[{ }^{\circ} \mathrm{C}\right]$ & $200 / 200 / 250$ \\
\hline & Cold tank heater capacity $\left[\mathrm{MW}_{\mathrm{e}}\right]$ & 0.02 \\
\hline & Hot tank heater temperature set point $\left[{ }^{\circ} \mathrm{C}\right]$ & 300 \\
\hline & Hot tank heater capacity $\left[\mathrm{MW}_{\mathrm{e}}\right]$ & 0.02 \\
\hline
\end{tabular}


$525 \quad$ Appendix 2: Values used for efficiency calculation of cycle with

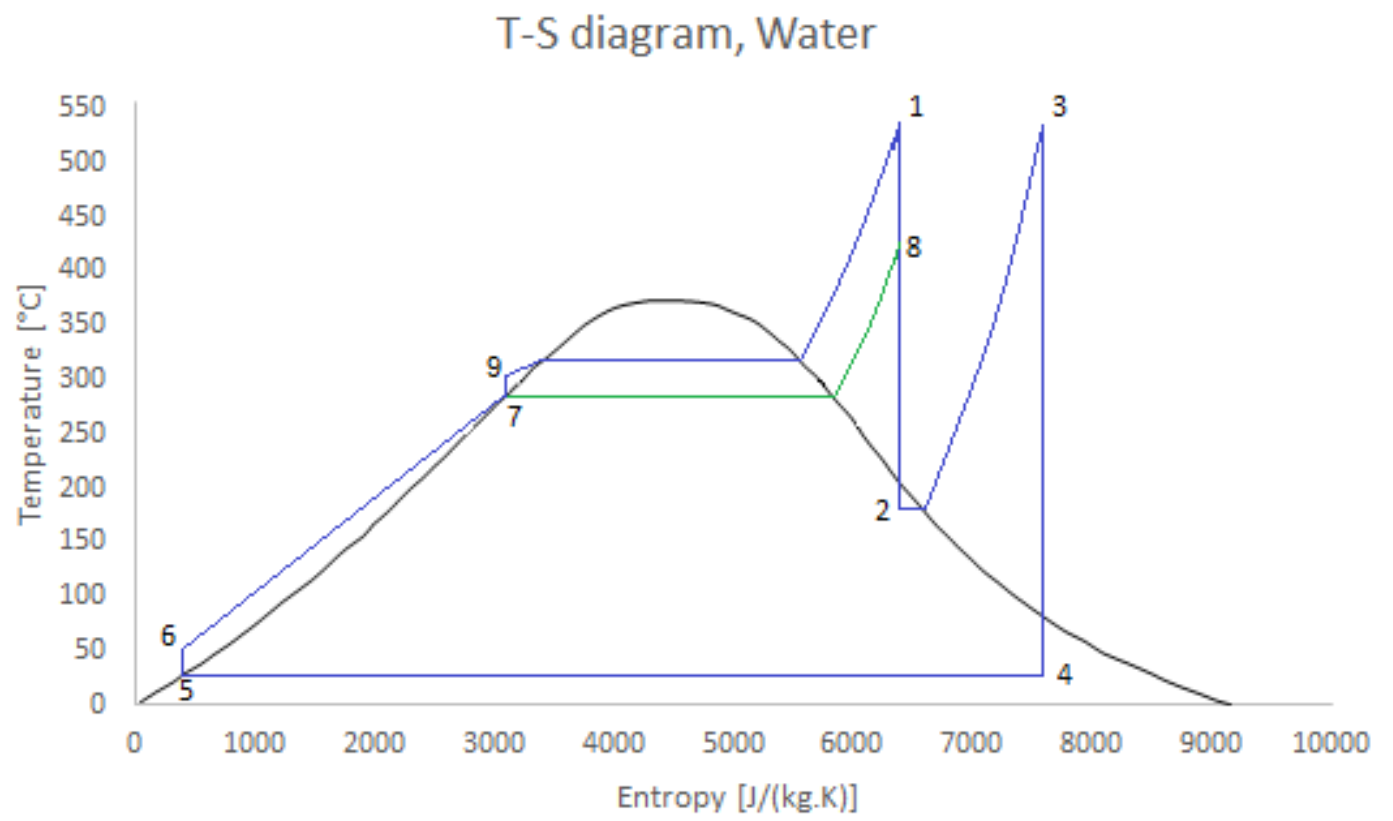

Figure 6: Rankine cycle with reheating and 1 bleeding at $290{ }^{\circ} \mathrm{C}$. 
Table 14: Values of pressure, temperature, mass flow and enthalpy for each point.

\begin{tabular}{c|cccc}
\hline \multicolumn{1}{c}{ Point } & Pressure [Bars] & $\begin{array}{c}\text { Temperature } \\
{\left[{ }^{\circ} \mathrm{C}\right]}\end{array}$ & $\begin{array}{c}\text { Mass flow } \\
{\left[\mathrm{kg} \cdot \mathrm{s}^{-1}\right]}\end{array}$ & $\begin{array}{c}\text { Enthalpy } \\
{\left[\mathrm{kJ} \cdot \mathrm{kg}^{-1}\right]}\end{array}$ \\
\hline 1 & 150 & 555 & 44.79 & 3461.71 \\
2 & 10 & 180 & 28.33 & 2833.19 \\
4 & 8 & 555 & 28.33 & 3599.81 \\
5 & 0.06 & 36.17 & 28.33 & 2594.38 \\
6 & 0.06 & 36.17 & 28.33 & 151.27 \\
7 & 74.36 & 37.95 & 28.33 & 158.7 \\
8 & 74.36 & 290 & 44.79 & 1289.64 \\
9 & 74.36 & 432.95 & 16.46 & 3236.5 \\
\hline 530 & 150 & 291.81 & 44.79 & 1297.20 \\
\hline
\end{tabular}

530

$$
\begin{aligned}
& \eta_{\text {cycle }} \\
& =\frac{m_{1}\left(h_{1}-h_{8}\right)+m_{2}\left(h_{8}-h_{2}\right)+m_{3}\left(h_{3}-h_{4}\right)-m_{5}\left(h_{6}-h_{5}\right)-m_{7}\left(h_{9}-h_{7}\right)}{m_{1}\left(h_{1}-h_{9}\right)+m_{3}\left(h_{3}-h_{2}\right)} \\
& =0.3972
\end{aligned}
$$




\section{T-S diagram, Water}

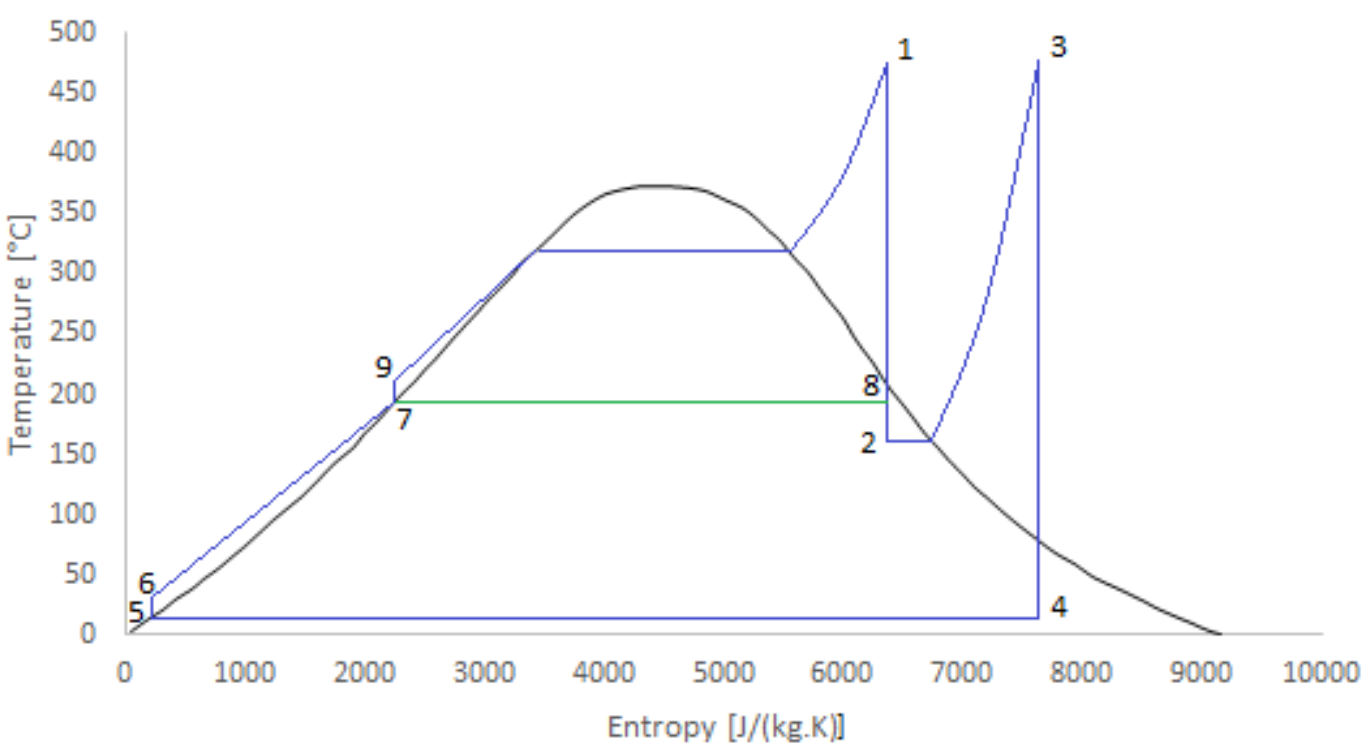

533

534

Figure 7: Rankine cycle with reheating and 1 bleeding at $200{ }^{\circ} \mathrm{C}$.

Table 15:Values of pressure, temperature, mass flow and enthalpy for each point.

\begin{tabular}{c|cccc}
\hline \multirow{2}{*}{ Point } & $\begin{array}{c}\text { Pressure } \\
{[\text { bars }]}\end{array}$ & $\begin{array}{c}\text { Temperature } \\
{\left[{ }^{\circ} \mathrm{C}\right]}\end{array}$ & $\begin{array}{c}\text { Mass flow } \\
{\left[\mathrm{kg} . \mathrm{s}^{-1}\right]}\end{array}$ & $\begin{array}{c}\text { Enthalpy } \\
{\left[\mathrm{kJ} . \mathrm{kg}^{-1}\right]}\end{array}$ \\
\hline 1 & 135 & 490 & 40.80 & 3300 \\
2 & 10 & 180 & 29.88 & 2750.17 \\
3 & 8 & 490 & 29.88 & 3458.71 \\
4 & 0.06 & 36.17 & 29.88 & 2530.09 \\
5 & 0.06 & 36.17 & 29.88 & 151.27 \\
6 & 15.54 & 36.54 & 29.88 & 152.82 \\
7 & 15.54 & 200 & 40.80 & 852.74 \\
8 & 15.54 & 200 & 10.93 & 2766.60 \\
9 & 135 & 202.86 & 40.80 & 864.69 \\
\hline
\end{tabular}




$$
\begin{gathered}
\eta_{\text {cycle }}=\frac{m_{1}\left(h_{1}-h_{8}\right)+m_{2}\left(h_{8}-h_{2}\right)+m_{3}\left(h_{3}-h_{4}\right)-m_{5}\left(h_{6}-h_{5}\right)-m_{7}\left(h_{9}-h_{7}\right)}{m_{1}\left(h_{1}-h_{9}\right)+m_{3}\left(h_{3}-h_{2}\right)} \\
=0.4104
\end{gathered}
$$

538 Appendix 4: Values used for efficiency calculation of complete cycle

\section{with HitecXL}

\section{T-S diagram, Water}

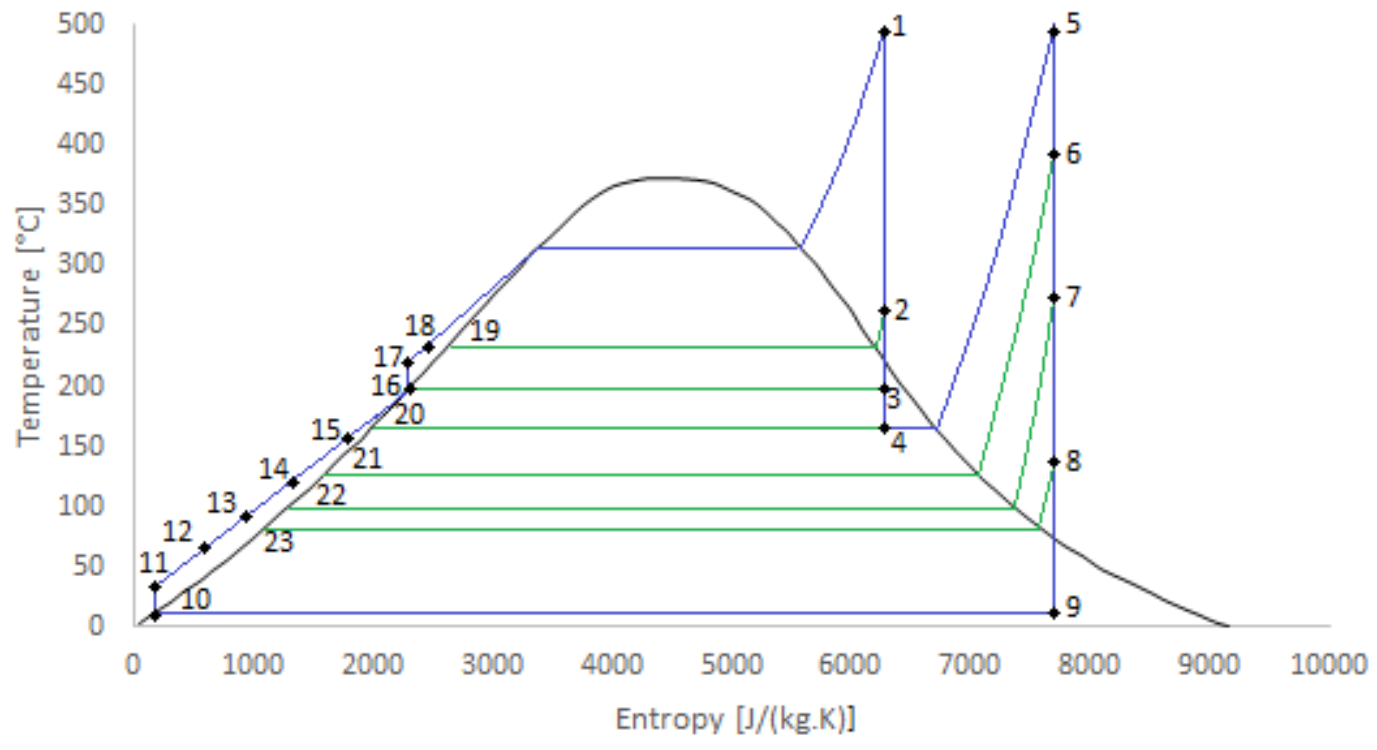

Figure 8: Complete cycle of direct storage with molten salts plant. 
Table 16: Values of pressure, temperature, mass flow and enthalpy for each point.

\begin{tabular}{|c|c|c|c|c|}
\hline Point & $\begin{array}{c}\text { Pressure } \\
\text { [bars] }\end{array}$ & $\begin{array}{c}\text { Temperature } \\
{\left[{ }^{\circ} \mathrm{C}\right]}\end{array}$ & $\begin{array}{c}\text { Mass flow } \\
{\left[\mathrm{kg} . \mathrm{s}^{-1}\right]}\end{array}$ & $\begin{array}{l}\text { Enthalpy } \\
{\left[\mathrm{kJ} \mathrm{kg}^{-1}\right]}\end{array}$ \\
\hline 1 & 135 & 490 & 40.05 & 3300 \\
\hline 2 & 27.95 & 257.32 & 2.16 & 2886.80 \\
\hline 3 & 15.54 & 200 & 3.42 & 2766.60 \\
\hline 4 & 10 & 180 & 2.18 & 2750.17 \\
\hline 5 & 8 & 490 & 32.29 & 3458.71 \\
\hline 6 & 2.7 & 324.73 & 1.51 & 3120.09 \\
\hline 7 & 1.01 & 202.46 & 1.69 & 2879.74 \\
\hline 8 & 0.31 & 84 & 1.40 & 2655.15 \\
\hline 9 & 0.06 & 36.17 & 27.70 & 2530.09 \\
\hline 10 & 0.06 & 36.17 & 34.47 & 151.27 \\
\hline 11 & 15.54 & 36.54 & 34.05 & 152.82 \\
\hline 12 & 15.54 & 66.65 & 34.05 & 268.04 \\
\hline 13 & 15.54 & 96.67 & 34.05 & 402.34 \\
\hline 14 & 15.54 & 126.67 & 34.05 & 528.62 \\
\hline 15 & 15.54 & 156.67 & 34.05 & 654.10 \\
\hline 16 & 15.54 & 200 & 40.05 & 852.74 \\
\hline 17 & 135 & 202.86 & 40.05 & 864.69 \\
\hline 18 & 135 & 227.29 & 40.05 & 966.81 \\
\hline 19 & 27.95 & 230 & 2.16 & 990.77 \\
\hline 20 & 10 & 180 & 2.18 & 763.18 \\
\hline 21 & 2.7 & 130 & 3.68 & 546.28 \\
\hline 22 & 1.01 & 100 & 5.38 & 419.71 \\
\hline 23 & 0.31 & 70 & 6.77 & 293.89 \\
\hline
\end{tabular}

543

544 
545 Appendix 5: Values used for efficiency calculation of complete cycle 546 with Solar Salt

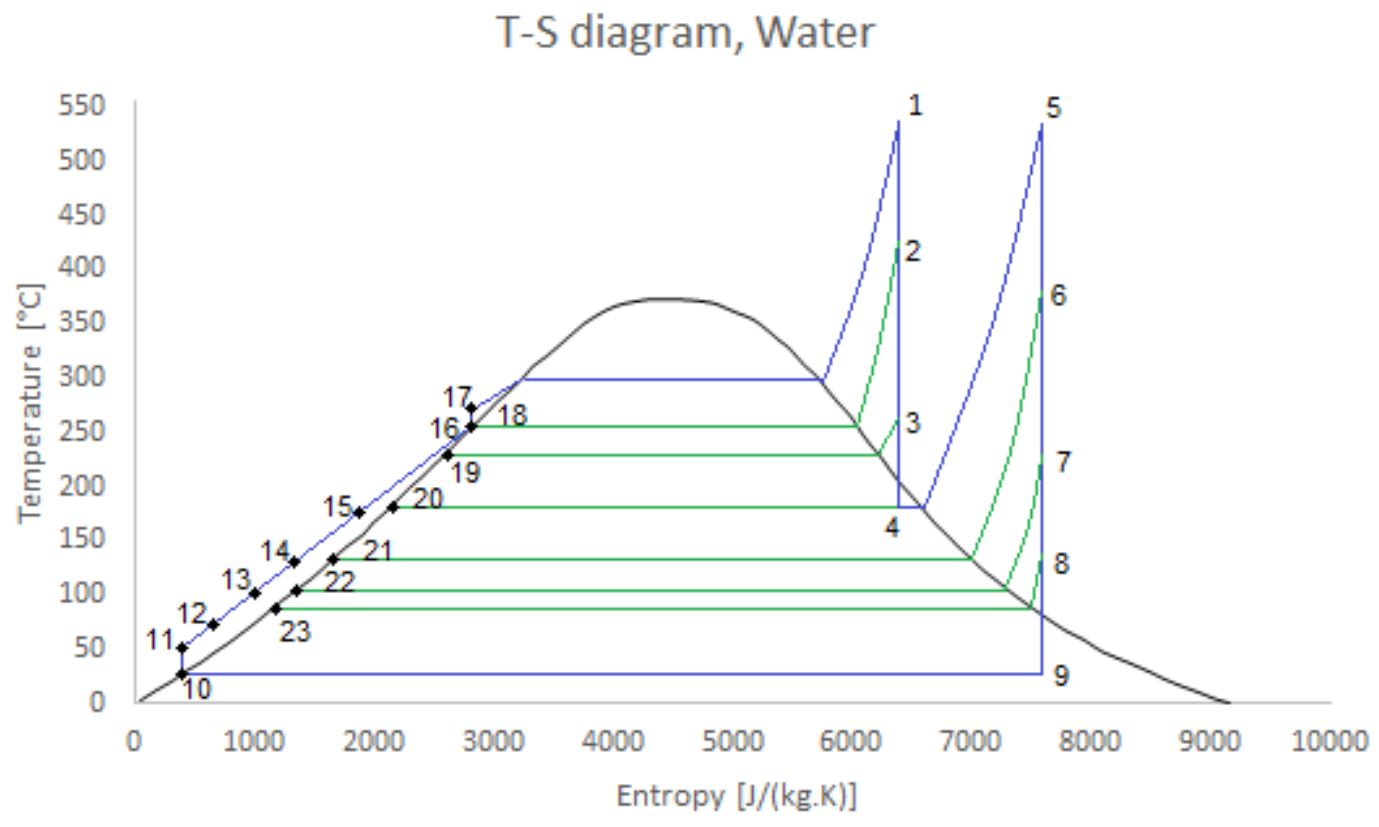


Table 17: Values of pressure, temperature, mass flow and enthalpy for each point.

\begin{tabular}{|c|c|c|c|c|}
\hline Point & $\begin{array}{l}\text { Pressure } \\
\text { [bars) }\end{array}$ & $\begin{array}{c}\text { Temperature } \\
{\left[{ }^{\circ} \mathrm{C}\right]}\end{array}$ & $\begin{array}{c}\text { Mass flow } \\
{\left[\mathrm{kg} . \mathrm{s}^{-1]}\right.}\end{array}$ & Enthalpy $\left[\mathrm{kJ} . \mathrm{kg}^{-1}\right]$ \\
\hline 1 & 150 & 555 & 39.62 & 3461.71 \\
\hline 2 & 74.36 & 432.95 & 4.37 & 3236.5 \\
\hline 3 & 27.95 & 290.31 & 3.51 & 2975.07 \\
\hline 4 & 10 & 180 & 3.08 & 2833.19 \\
\hline 5 & 8 & 555 & 28.66 & 3599.81 \\
\hline 6 & 2.7 & 380.36 & 1.23 & 3234.39 \\
\hline 7 & 1.01 & 245.7 & 1.35 & 2965.46 \\
\hline 8 & 0.31 & 119.43 & 1.34 & 2722.08 \\
\hline 9 & 0.06 & 36.17 & 24.74 & 2594.38 \\
\hline 10 & 0.06 & 36.17 & 31.74 & 151.27 \\
\hline 11 & 27.95 & 36.84 & 31.74 & 154.06 \\
\hline 12 & 27.95 & 66.68 & 31.74 & 278.82 \\
\hline 13 & 27.95 & 96.67 & 31.74 & 404.15 \\
\hline 14 & 27.95 & 126.67 & 31.74 & 529.55 \\
\hline 15 & 27.95 & 174.67 & 31.74 & 730.19 \\
\hline 16 & 27.95 & 230 & 39.62 & 990.77 \\
\hline 17 & 150 & 232.92 & 39.62 & 1002.98 \\
\hline 18 & 150 & 284.29 & 39.62 & 1217.71 \\
\hline 19 & 74.36 & 290 & 4.37 & 1289.64 \\
\hline 20 & 10 & 180 & 3.08 & 763.18 \\
\hline 21 & 2.7 & 130 & 4.31 & 546.28 \\
\hline 22 & 1.01 & 100 & 5.66 & 419.71 \\
\hline 23 & 0.31 & 70 & 7 & 293.89 \\
\hline
\end{tabular}

550

551 


\begin{tabular}{|c|c|c|c|c|}
\hline \multirow[b]{5}{*}{ First method (with } & \multicolumn{4}{|c|}{ Annual } \\
\hline & CAPEX & OPEX & electricity & LCOE \\
\hline & {$[\mathrm{M} \$] /[\mathrm{M} €]$} & {$[\mathrm{M} \$] /[\mathrm{M} €]$} & (produced) & {$[\mathrm{c} \$ / \mathrm{kWh}] /[\mathrm{c} € / \mathrm{kWh}]$} \\
\hline & & & [MWh]] & \\
\hline & & & & \\
\hline SAM) & $339.5 / 303.55$ & $3.25 / 2.92$ & 164,565 & $18.99 / 16.98$ \\
\hline $\begin{array}{c}\text { Second method } \\
\text { (manual calculation) }\end{array}$ & $339.5 / 303.55$ & $3.25 / 2.92$ & 133,577 & $17.92 / 16.02$ \\
\hline
\end{tabular}

554

555 


\begin{tabular}{c|c|c|c}
\cline { 2 - 3 } & $\begin{array}{c}\text { Conventional } \\
\text { plant }\end{array}$ & $\begin{array}{c}\text { Direct storage } \\
\text { HitecXL } \\
\eta_{\text {cycle }}\end{array}$ & $\begin{array}{c}\text { Direct storage } \\
\text { Solar Salt } \\
\eta_{\text {cycle }}\end{array}$ \\
\hline Basic cycle & $24.64 \%$ & $34.34 \%$ & $35.22 \%$ \\
Cycle w/ reheating & $64.02 \%$ & $61.47 \%$ & $61.32 \%$ \\
Cycle w/ reheating and one bleeding & $65.32 \%$ & $66.19 \%$ & $64.11 \%$ \\
Cycle w/ reheating and two bleedings & $66.55 \%$ & $67.35 \%$ & $65.98 \%$ \\
Cycle w/ reheating and three bleedings & $67.88 \%$ & $67.82 \%$ & $66.97 \%$ \\
Cycle w/ reheating and four bleedings & $68.66 \%$ & $67.97 \%$ & $67.42 \%$ \\
Cycle w/ reheating and five bleedings & $69.70 \%$ & $68.06 \%$ & $67.80 \%$ \\
\hline Complete cycle & $71.04 \%$ & $68.60 \%$ & $68.58 \%$ \\
\hline
\end{tabular}

